WSRC-TR-96-0416

Publication Dáte: March 1997

\title{
EVALUATION OF THE PURGE WATER MANAGEMENT SYSTEM (PWMS) MONITOR WELL SAMPLING TECHNOLOGY AT SRS
}

R. A. Hiergesell

J. E Cardoso-Neto

D. W. Williams

Westinghouse Savannah River Company Savannah River Site

Aiken, SC 29808

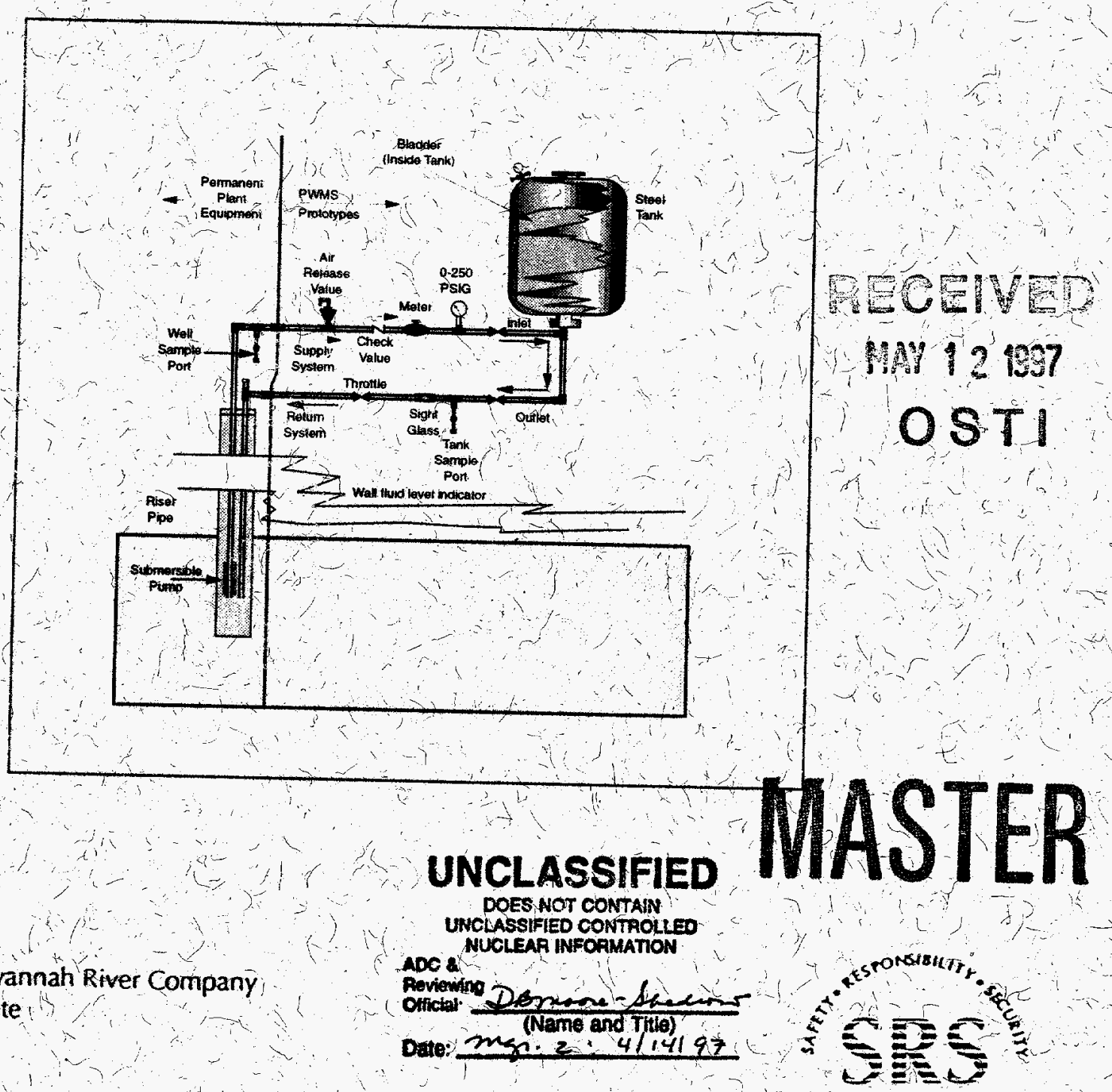

Prepared for the U: S. Department of Energy under Contract No. DE-ACO9-B9SR18035 


\section{DISCLAMMER}

This report was prepared as an account of work sponsored by an agency of the United States Government. Neither the United States Government nor any agency thereof, nor any of their employees, makes any warranty, express or implied, or assumes any legal liability or responsibility for the accuracy, completeness, or usefulness of any information, apparatus, product, or process disclosed, or represents that its use would not infringe privately owned rights. Reference herein to any specific commercial product, process, or service by trade name, trademark, manufacturer, or otherwise does not necessarily constitute or imply its endorsement, recommendation, or favoring by the United States Government or any agency thereof. The views and opinions of authors expressed herein do not necessarily state or reflect those of the United States Government or any agency thereof.

This report has been reproduced directly from the best available copy.

Available to DOE and DOE contractors from the Office of Scientific and Technical Information, P.O. Box 62, Oak Ridge, TN 37831; prices available from (615) 576-8401.

Available to the public from the National Technical Information Service, U.S. Department of Commerce; 5285 Port Royal Road, Springfield, VA 22161. 
WSRC-TR-96-0416

Publication Date: March 1997

\title{
EVALUATION OF THE PURGE WATER MANAGEMENT SYSTEM (PWMS) MONITOR WELL SAMPLING TECHNOLOGY AT SRS
}

\author{
R. A. Hiergesell \\ J. E. Cardoso-Neto \\ D. W. Williams
}

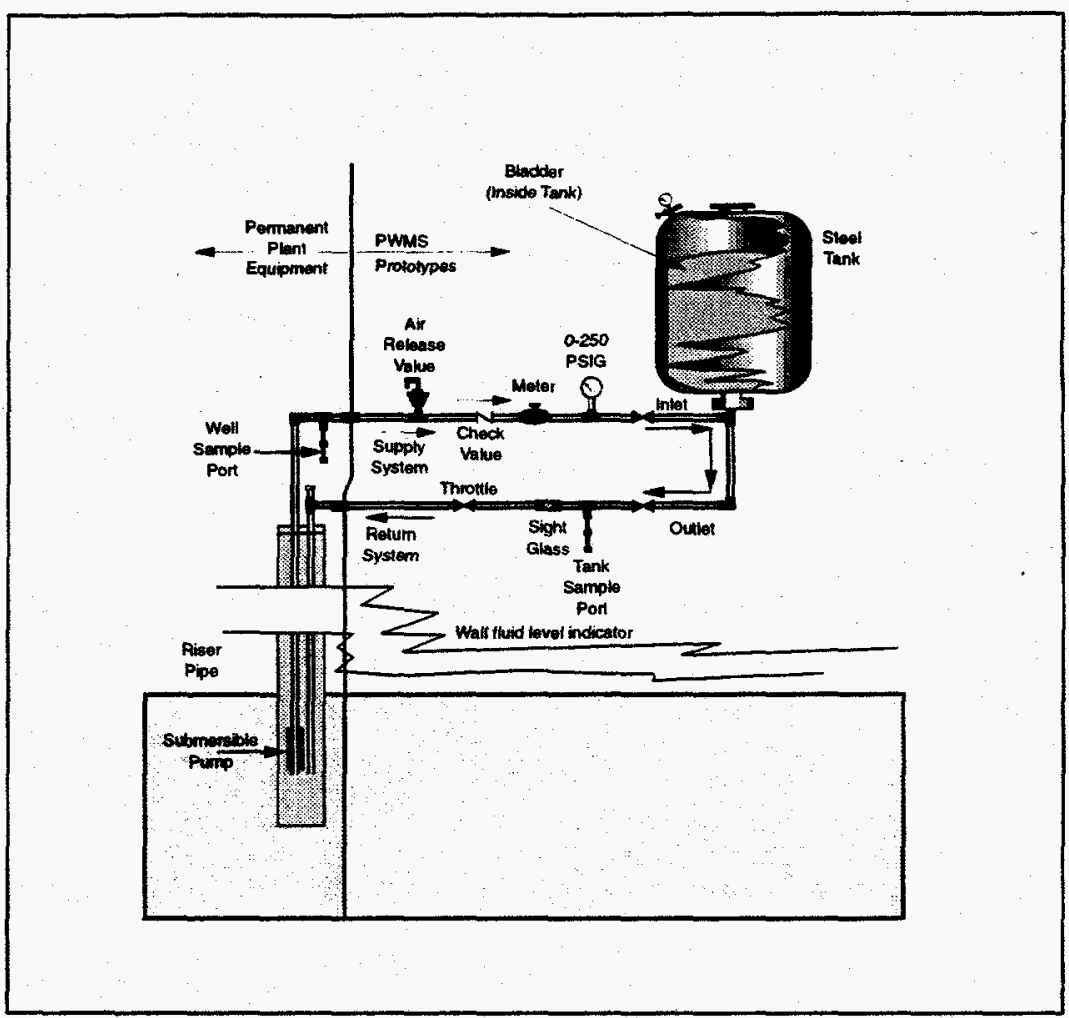

Westinghouse Savannah River Company

Savannah River Site

Aiken, SC 29808

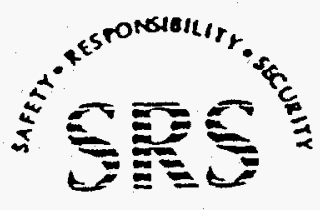

Prepared for the U. S. Department of Energy under Contract No. DE-AC09-89SR18035 


\section{DISCLAOMER}

Portions of this document moy be illegible in electronic image products. Impges are produced from the best available original docomenter. 


\section{TABLE OF CONTENTS}

Executive Summary ............................................................................. 1

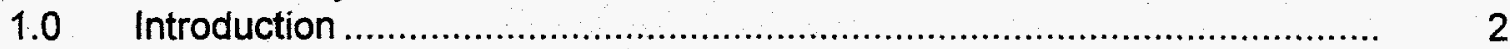

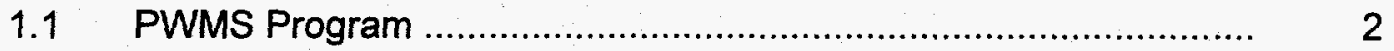

2.0 Field Testing Methods and Procedures ............................................ 2

2.1 Description of PWMS ............................................................. 2

$2.2 \quad$ Initial Field Operations ........................................................... 4

2.3 Phase I Sampling .................................................................. 5

2.4 Phase II Sampling …......................................................... 5

2.5 Special Sampling Event ...................................................... 5

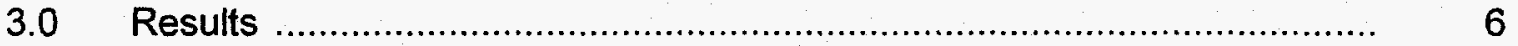

3.1 Aluminum .................................................................. $\quad 7$

3.2 Calcium ....................................................................... 7

3.3 Carbon Tetrachloride ........................................................... 8

3.4 Chloride ......................................................................... 8

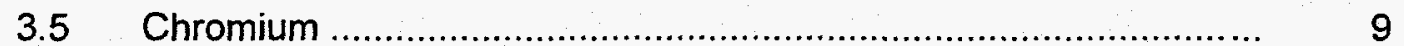

3.6 Gross Alpha ..................................................................... 9

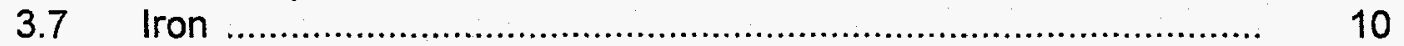

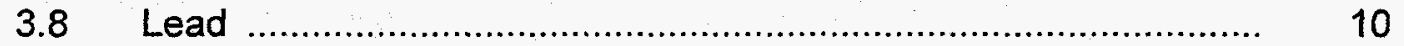

3.9 Manganese ....................................................................... 11

$3.10 \mathrm{pH}$................................................................................. 11

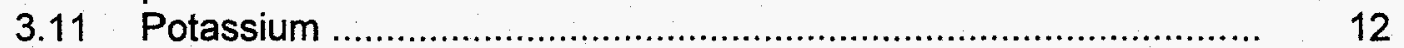

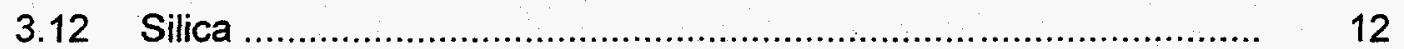

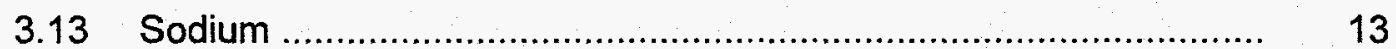

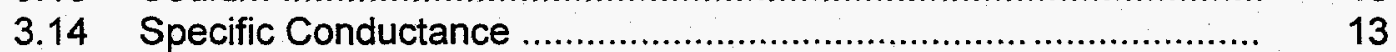

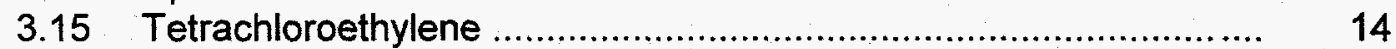

3.16 Trichloroethylene ............................................................. 14

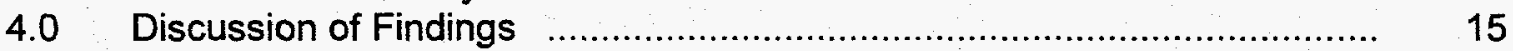

5.0 Conclusions and Recommendations ............................................. 19

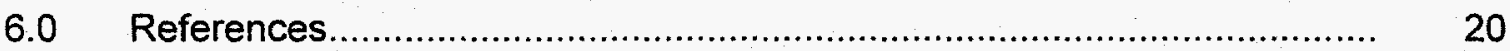

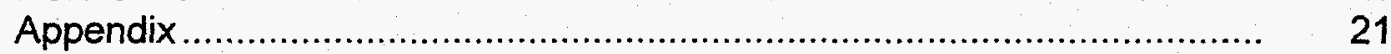

\section{LIST OF FIGURES}

Figure 1 Location of MCB-5 Test Site relative to the AMM Area ....................... 2

Figure 2 Schematic diagram of bladder tank apparatus ................................ 4

\section{LIST OF TABLES}

Table 1 Calculated averages for Historical, PWMS Influent, and PWMS Effluent results. 


\section{EXECUTIVE SUMMARY}

Due to the complex issues surrounding Investigation Derived Waste (IDW) at SRS, the Environmental Restoration Division has been exploring new technologies to deal with the purge water generated during monitoring well sampling. Standard procedures for sampling generates copious amounts of purge water that must be managed as hazardous waste, when containing hazardous and/or radiological contaminants exceeding certain threshold levels.

SRS has obtained Regulator approval to field test an innovative surface release prevention mechanism to manage purge water. This mechanism is referred to as the Purge Water Management System (PWMS) and consists of a collapsible bladder situated within a rigid metal tank. The PWMS is connected to a monitoring well. A submersible pump in the well pumps groundwater through the piping system into the expandable container. After the required volume of groundwater has been purged from the well, the protocol sample is drawn from the well sampling port, after which the purge water inside the bladder is returned to the well through the return system. Handling of purge water in this closed-system ensures that the purged groundwater is isolated from the environment, especially from oxygen in the atmosphere, which might cause constituents in the water to oxidize.

Field testing of the PWMS was conducted in 1996 in the monitoring well MCB-5, located near the Miscellaneous Chemicals Basin. Testing was conducted in three separate sampling events and the results were the subject of the analysis in this report. Evaluation of the analytical results obtained during the Phase I, Phase II and the 9/18/96 sampling events at MCB-5 indicates that samples collected using the PWMS sampling method provide analysis results that are very similar to historical analysis results obtained from routine monitoring. Based on this observation it is reasonable to conclude that representative groundwater samples are being collected using the PWMS. This conclusion is indicated not only for background analytes, but also for contaminants that have been released to the subsurface in the vicinity of the Miscellaneous Chemicals Basin. 


\section{$1.0 \quad$ INTRODUCTION}

Standard procedure for obtaining groundwater samples at SRS calls for purging enough groundwater to allow certain key indicator parameters to stabilize prior to collection of samples. As a result a certain volume of water must be extracted from a well before a protocol sample can be collected. The water extracted from a well prior to sample collection is termed "purge water" and must be managed in an approved fashion if it contains hazardous and/or radiological constituents that exceed specified threshold limits described in the Investigation Derived Waste (IDW) Management Plan, Rev. 2. Typical handling practices include containerization, treatment and/or disposal as a hazardous waste.

\section{$1.1 \quad$ PWMS Program}

A new method for handling purge water that avoids the need to containerize and transport this water to a suitable disposal facility has been developed. This method is termed the Purge Water Management System (PWMS) and is a closed-loop, noncontact system used to return purge water back to the originating aquifer after a sampling event without having significantly altered the water quality. The method has recently been evaluated at both a "clean" well (P-26D) and at a "contaminated" well (MCB-5) to compare results obtained during PWMS sampling and the historical record from each of these wells.

The PWMS testing at the clean well, P-26D, was conducted as a precursor to the demonstration of the technology at monitoring well MCB-5. Historical concentrations have not exceeded the Primary Drinking Water Standards (PDWS) at monitoring well P-26D. Key field parameters and analytes, including $\mathrm{pH}$, specific conductance, iron, lead, and potassium were selected for analysis to determine if the sampling methodology impacted the groundwater chemistry in any way.

The analyses from the PWMS test were compared to the historical analyses of the water from P-26D, a well which is sampled quarterly as a background well for the TNX Area. In addition, analysis from the PWMS influent were compared with samples from the effluent. Test results from this investigation have previously been reported and indicate that the use of the PWMS did not significantly alter groundwater quality. [Reference of Previous Work]

\section{Evaluation Study at MCB-5}

This investigation extends previous work conducted at P-26 to examine any effects that might occur at a well that has historically exhibited elevated levels of regulated contaminants. The well selected for this phase of the evaluation was MCB-5, located close to the Miscellaneous Chemicals Basin in the A/M Area. Location can be noted on Figure 1. MCB-5 has a history of elevated concentrations of TCE and PCE.

Purpose of this investigation is to evaluate the impact of the PWMS upon groundwater quality particularly in comparison to records of groundwater quality obtained from historical sampling events.

\subsection{FIELD TESTING METHODS AND PROCEDURES}

\subsection{Description of PWMS}

The PWMS consists of a collapsible bladder situated within a tank, a supply system and a return system. The apparatus is illustrated below in Fig. 2. A submersible pump located within MCB-5 supplied water to 


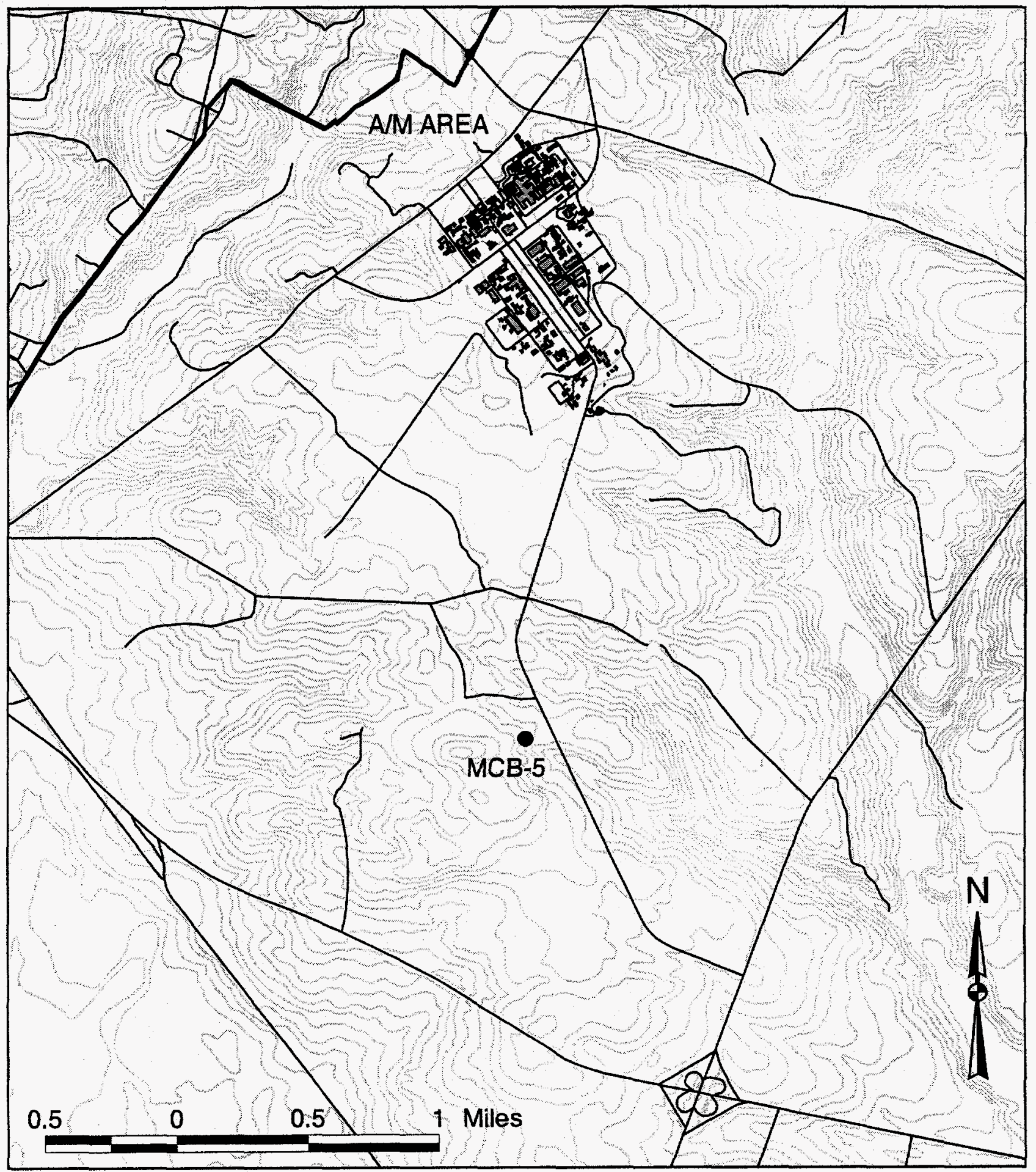

Figure 1. Location of MCB-5 Test Site relative to A/M Area 
PWMS. A series of valves allow delivery of purge water to the bladder where it is housed until such time when it is returned to the originating aquifer, back through the well. Handling of purge water in the closed- system ensures that the water is isolated from the environment, especially from oxygen in the atmosphere, which might cause constituents in the water to oxidize.

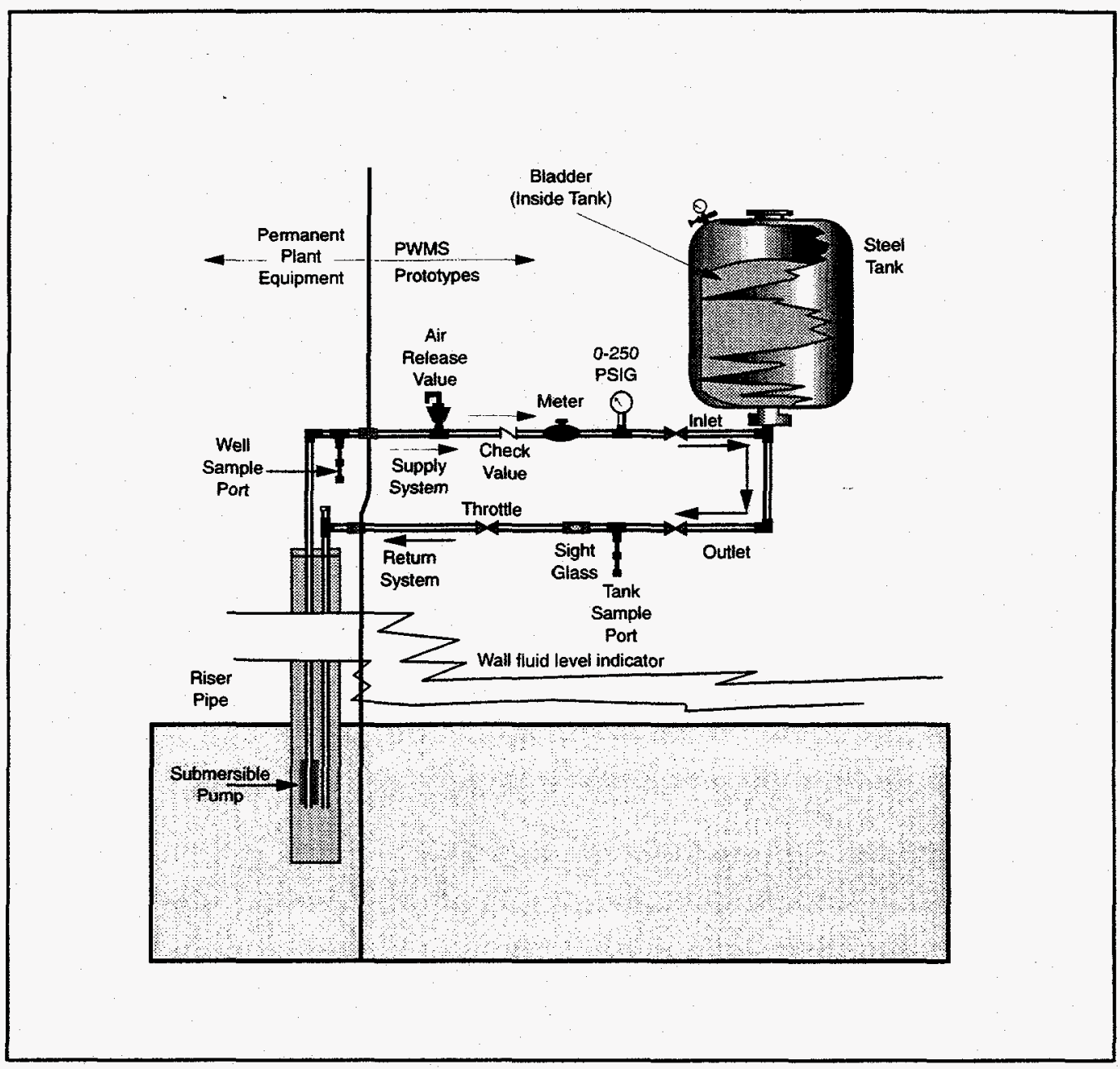

Figure 2 Schematic design of the PWMS prototype.

\subsection{Initial Field Operations}

The bladder tank was flushed with water at the well building on $7 / 31 / 96$. Samples were collected of rinsate prior to filling the bladder tank and again during draining of the bladder tank. Samples were labeled EPT-1 (influent) and EPT-2 (effluent). Following this, the PWMS was transported to the MCB-5 site for the field trial. 


\subsection{Phase I Sampling}

The initial test at MCB-5 was conducted on $8 / 1 / 96$ and is referred to as the Phase I sampling event. Groundwater was pumped from MCB-5 into the bladder tank. The field parameters specific conductance, water temperature, $\mathrm{pH}$, and turbidity were all monitored at the well sampling port to determine the point at which their levels stabilized. The pumping rate was regulated at approximately 3 gallons per minute (gpm). Specific conductance, water temperature, and $\mathrm{pH}$ varied little during initial pumping, however turbidity initially was measured at 11.9 ntu's and gradually decreased to 2.6 ntu's after approximately 34 minutes. The initial sample, MCB-5-I, was collected at this time and pumping was then terminated. After a short period of time, the water that was collected in the bladder tank was drained into a mobile water tanker. A gate valve was used to regulate flow at $2 \mathrm{gpm}$ and following the gravity draining, air pressure was applied to the tank to assure that the bladder completely deflated. During this tank effluent flow event another sample, MCB-5$O$, was collected as were quality assurance samples. The quality assurance samples included duplicate, split, and field blank samples. Again, the same field parameters were monitored during the tank effluent event but did not vary, even for turbidity, which was stable at approximately 3.2 ntu's.

\subsection{Phase II Sampling}

A second test was conducted at MCB-5 on $8 / 20 / 96$ and is referred to as the Phase II sample event. Groundwater was again pumped into the bladder tank. During this time, field parameters specific conductance, water temperature, $\mathrm{pH}$ and turbidity were again monitored to determine the point at which they stabilized. The pumping rate was regulated at approximately $2 \mathrm{gpm}$. Water temperature was constant throughout the pumping event at 21.0 degrees $\mathrm{C}$. Specific conductance, $\mathrm{pH}$, and turbidity all varied slightly throughout the pumping period but had re-stabilized prior to collection of the sample. All three field parameters reached peak values of 54 uS $/ \mathrm{cm}, 8.0$, and 8.4 ntu's after 6 minutes of pumping and gradually re-equilibrated following this. Restablized values for these parameters were $3.0 \mathrm{uS} / \mathrm{cm}, 6.6$ and 3.1 ntu's, for specific conductance, $\mathrm{pH}$ and turbidity, respectively. Re-stabilization for all three parameters occurred approximately 20 minutes following initiation of pumping. The initial sample, MCB-5-I, was collected at this time and then pumping was terminated. After a short period of time, the water that was collected in the bladder tank was drained back into MCB-5. A gate valve was used to regulate flow at slightly less than $2 \mathrm{gpm}$ and following the gravity draining, air pressure was applied to the tank to assure that the bladder completely deflated. During the return flow event another sample MCB-5-O was collected. The field blank sample, EPT-3, was collected at an earlier time, before the pumping event took place.

\subsection{Special Sampling Event}

One final groundwater sampling event took place at MCB-5 on 9/18/96 and is referred to as the Special Sampling Event. This event was not a part of the regularly scheduled groundwater monitoring at MCB5 . During the event purge water from MCB5 was discharged into a mobile tanker until such time that field parameters stabilized and a sample could be collected. After collection of the sample groundwater pumping was terminated and the purge water was transported to an air stripper for disposal. During pumping, field parameters specific conductance, water temperature, $\mathrm{pH}$ and turbidity were again monitored to determine the point at which they stabilized. Specific conductance varied from 24 to 54 uS $/ \mathrm{cm}$ but stabilized at 30 uS/cm after 19 minutes. Water temperature was constant 
throughout at 21 degrees $C$. The initial value of $\mathrm{pH}$ was 6.0 but later stabilized at 6.6. Turbidity peaked shortly after initiation of pumping at $8.4 \mathrm{ntu}$ and later stabilized at approximately $3.1 \mathrm{ntu}$ after 22 minutes of continuous pumping. The sample, MCB-5, was collected shortly after turbidity stabilized.

\subsection{RESULTS}

To evaluate sample analyses obtained from the PWMS investigation the results of sampling were compared to historical concentrations of selected analytes obtained from samples collected at MCB-5. Initially, a list of selected analytes and field parameters was developed so that the comparisons could be made. List of key analytes and field parameters for which concentrations were analyzed include: Aluminum, Calcium, Carbon Tetrachloride, Chromium, Gross Alpha, Iron, Lead, Manganese, pH, Potassium, Silica, Sodium, Specific Conductance, Trichloroethylene, and Tetrachloroethylene. All available historical data for these parameters was downloaded from the Geochemical Information Management System (GIMS) database. The data was processed to deal with analysis qualifiers, QA samples and results reported as being less than detection limits.
On the following pages a series of scatter charts are presented showing the results of all analyses conducted for the above mentioned analytes and/or parameters at MCB-5. Values of analyses reported as less than the detection limit are shown with a different symbol on the charts. These charts show analysis results for all previous analyses conducted at MCB-5. Also shown are results from analyses conducted during the PWMS investigation sampling events from 8/1/96, 8/20/96, and 9/18/96. Different symbols are used to distinguish analysis results from the historical record and from the PWMS investigation. The historical data were obtained from the GIMS database and was screened to eliminate analyses with results qualifiers rendering the data not usable. Data reported as either "off-scale high" or "rejected because performance objectives were not met" were eliminated. Data reported as "not detected, result reported is less than sample quantitation limit" were utilized in the scatter charts and are illustrated using a gray-scale symbol, as shown in the legend of each chart. The data were processed to combine multiple samples from the same date when duplicate, replicate, and split samples were collected at a single sample event. A single value reflecting the average of multiple values is posted on the scatter charts when that situation occurs. Also, a brief narrative is provided with each chart to describe general trends and features and to highlight the comparison of the PWMS field trial concentrations/values with historical levels. 
3.1 Aluminum The historical trend in aluminum concentrations at MCB- 5 shows that values ranged from approximately $40 \mathrm{ug} / \mathrm{L}$ to $160 \mathrm{ug} / \mathrm{L}$. Concentrations obtained in this investigation appear to be very similar to the historical record, with one value being slightly higher and two values slightly lower than historical concentrations. The higher values in the PWMS investigation are from the effluent sampling event which sampled the water mixed in the bladder tank during the influent sampling event. The relatively turbid water, avoided when collecting the influent sample, was sampled and has evidently effected the concentrations results for certain analytes associated with colloids and clay molecules.

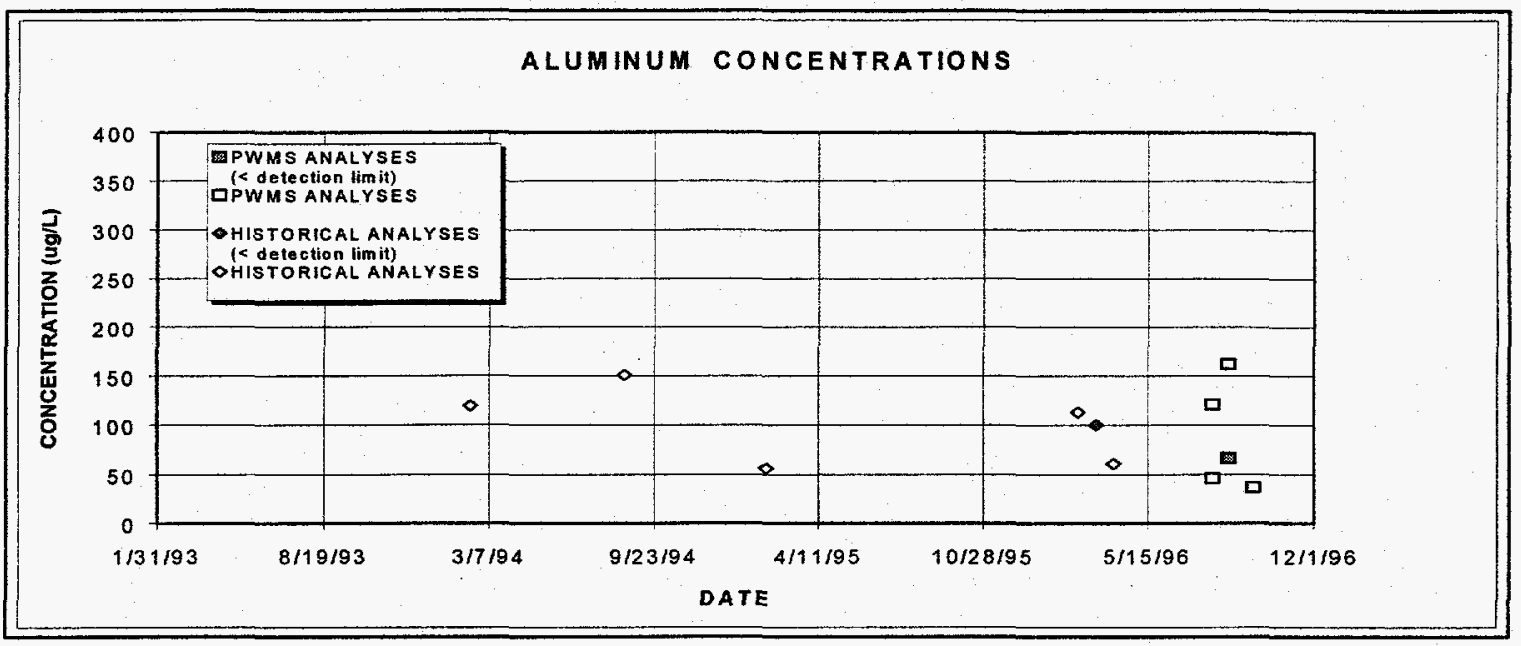

\subsection{Calcium Very few analyses} have been conducted for Calcium at MCB-5 in the past. Only three previous analyses, all from earlier in 1996, were obtained from the database. The range of these values was from approximately $2100 \mathrm{ug} / \mathrm{L}$ to 6300 $u g / L$ and was very similar to the concentrations obtained in the PWMS

investigation. PWMS analyses clustered around $5000 \mathrm{ug} / \mathrm{L}$ except for the sample obtained in the special sampling event on $9 / 18 / 96$, which yielded a concentration of $124 \mathrm{ug} / \mathrm{L}$. The reason for this anomalously low concentration is not known, however the other analyses are all well within the range of previous analytical results.

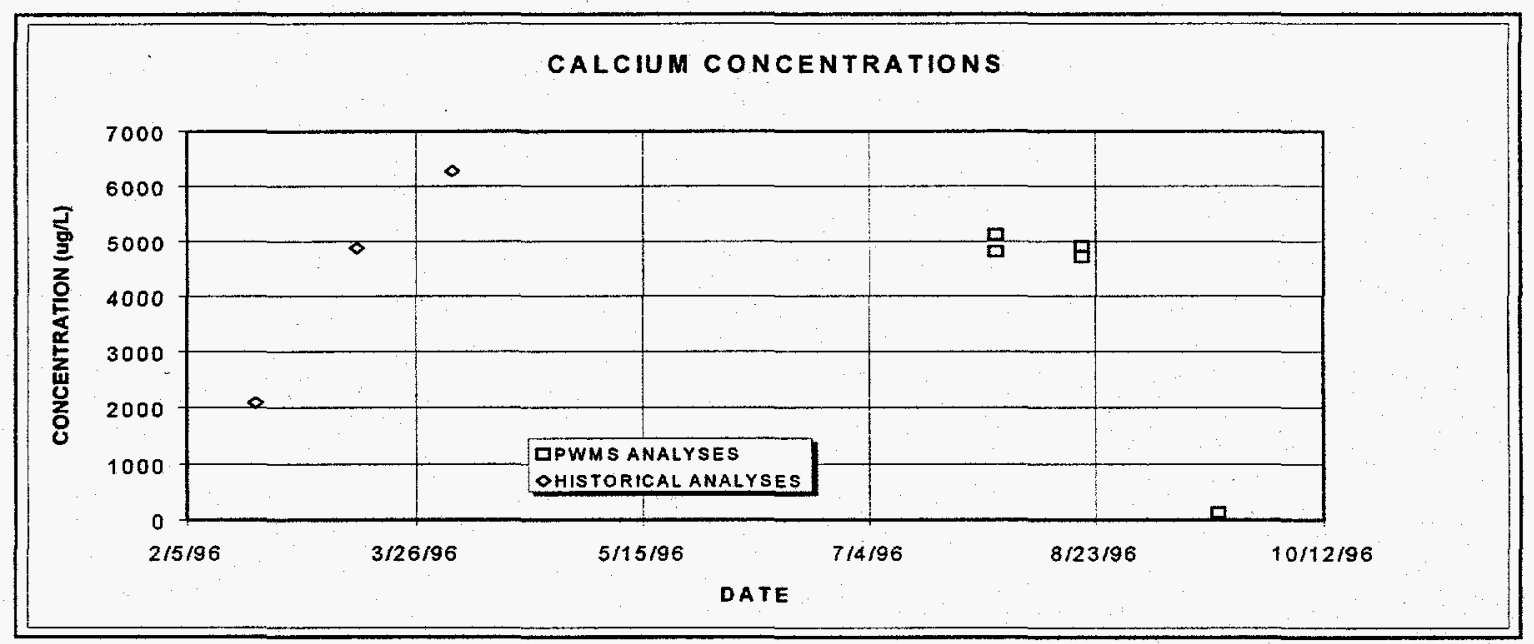




\subsection{Carbon Tetrachloride Historical} Carbon Tetrachloride concentrations range from less than $1 \mathrm{ug} / \mathrm{L}$ to $14 \mathrm{ug} / \mathrm{L}$. Most concentrations are clustered around the 5 $\mathrm{ug} / \mathrm{L}$ level, which is slightly higher than the 4
ug/L level that the PWMS investigation samples tightly cluster around. These concentrations are practically identical to the majority of historical concentrations monitored at MCB-5.

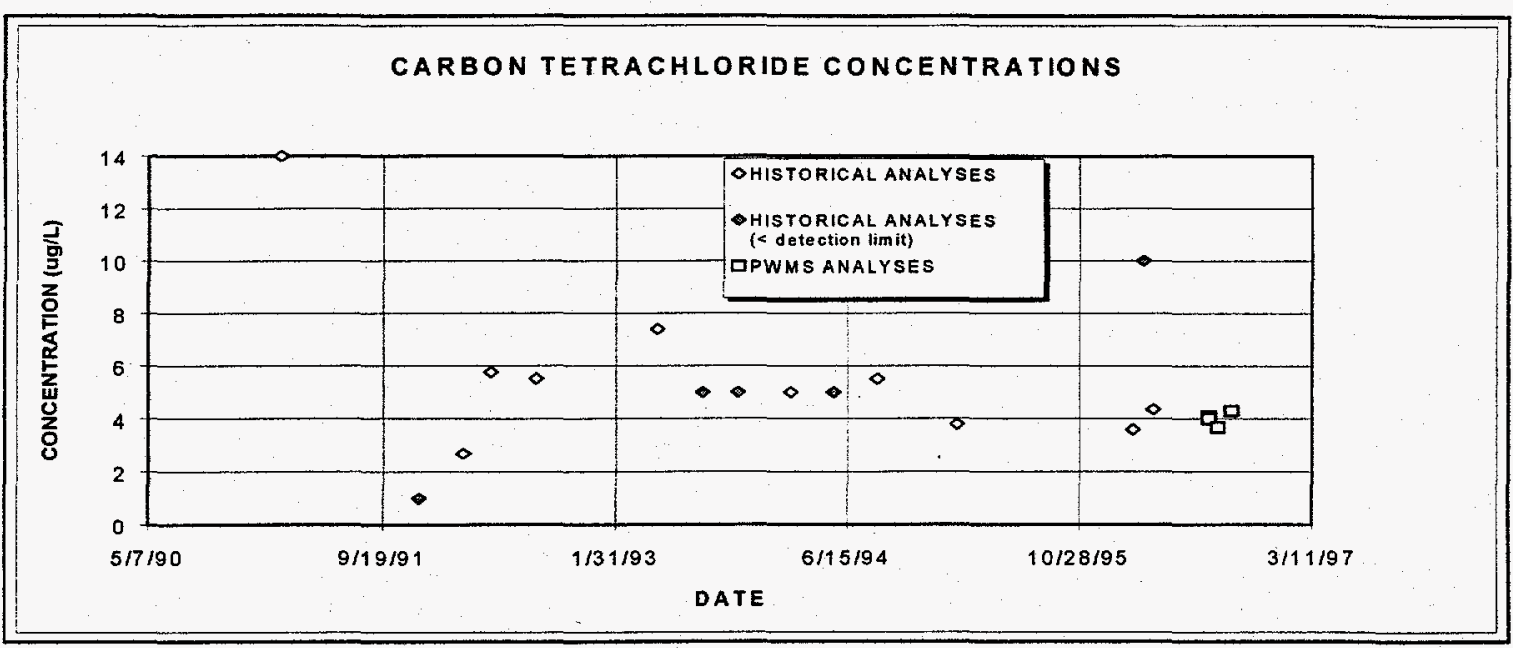

\subsection{Chloride Only four historical} measurements were found in the groundwater chemistry database, ranging in concentration from approximately $1300 \mathrm{ug} / \mathrm{L}$ to just over $2000 \mathrm{ug} / \mathrm{L}$. The PWMS investigation sample concentrations all fall within this range, clustering around 1750 ug/L.

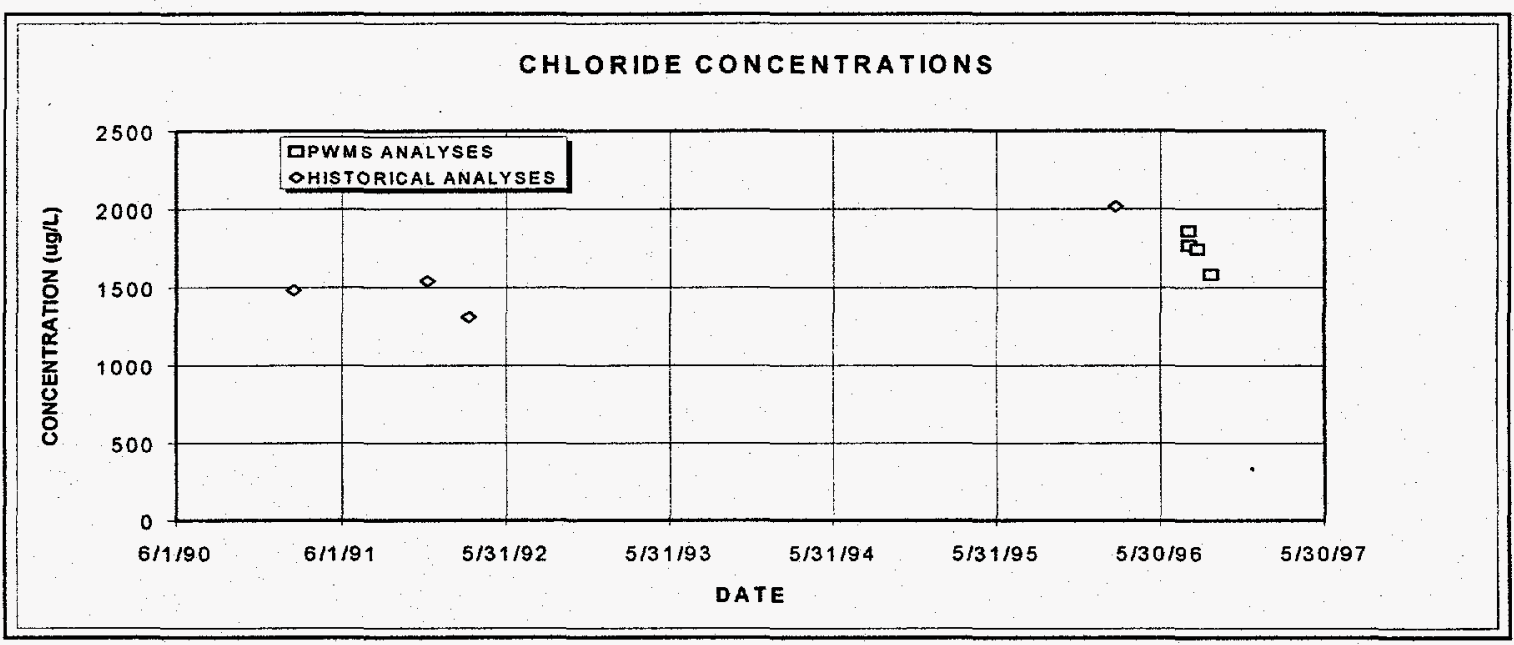


3.5 Chromium Three historical analyses for chromium have been conducted at MCB-5, only two of which are usable for comparison with the PWMS investigation samples. The two concentrations are both approximately 2 $\mathrm{ug} / \mathrm{L}$ while the PWMS sample concentrations also clustered around 2 $\mathrm{ug} / \mathrm{L}$.

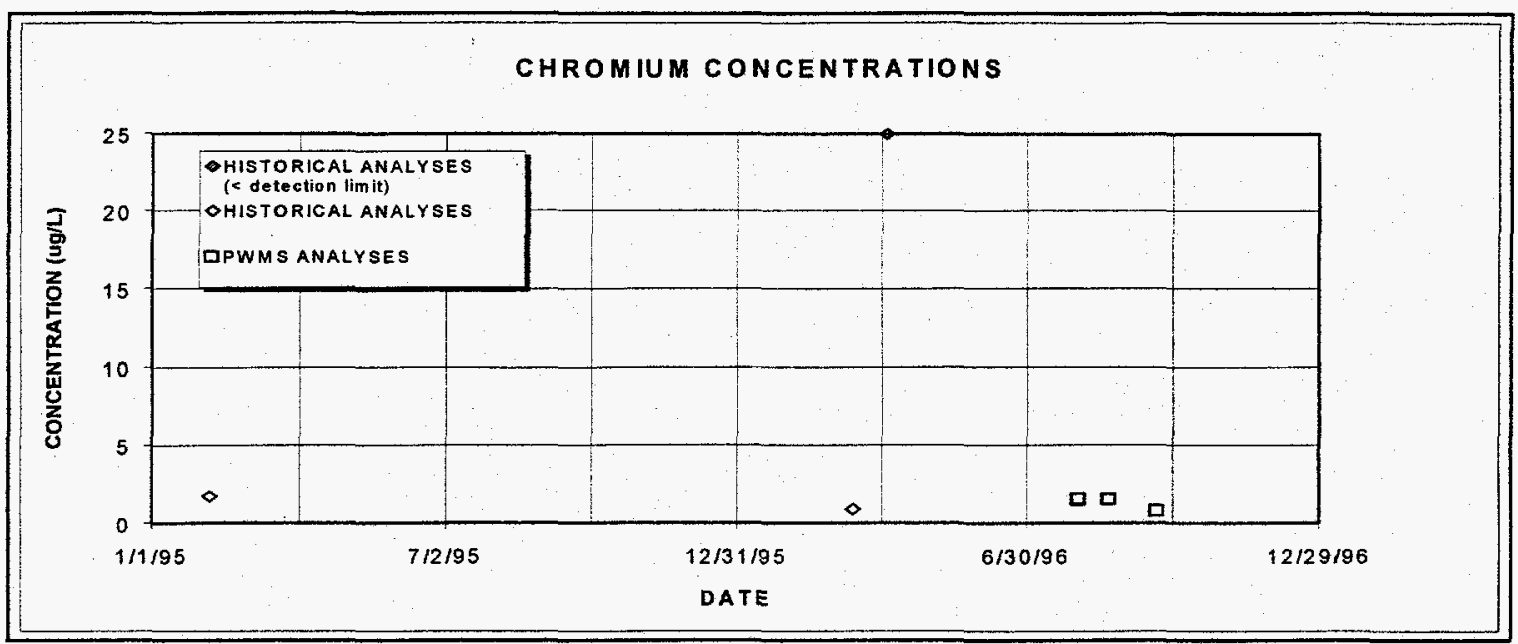

3.6 Gross Alpha Historical Gross Alpha activity at MCB-5 indicates a gradually decreasing trend, starting with values clustered around $2 \mathrm{pCi} / \mathrm{L}$ and decreasing to approximately $0.5 \mathrm{pCi} / \mathrm{L}$ in early 1996. The PWMS analyses obtained Gross Alpha activities clustering around 1.3 $\mathrm{pCi} / \mathrm{L}$, which is similar to the average activity from all historical analyses.

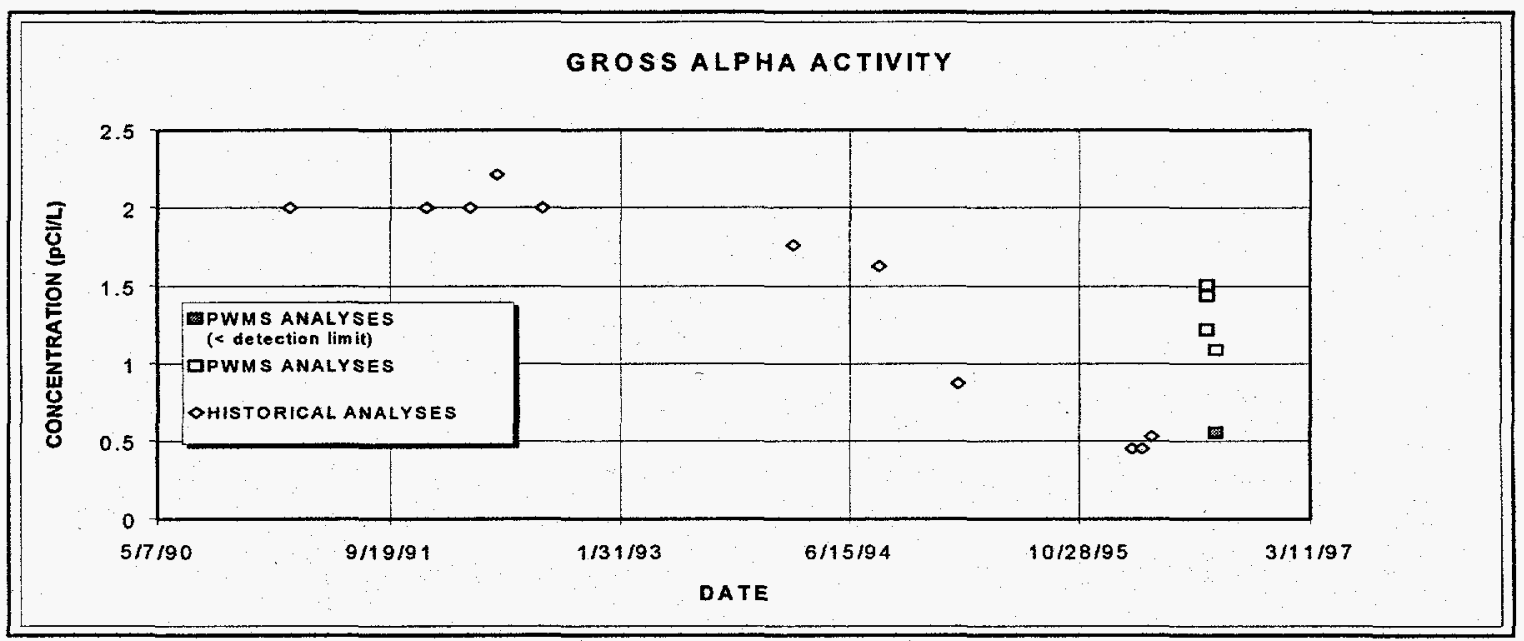


3.7 Iron Historical concentrations of Iron at MCB-5 have ranged from near 12 $\mathrm{ug} / \mathrm{L}$ to $993 \mathrm{ug} / \mathrm{L}$. The highest concentration is in a single value whose validity must be regarded as questionable. All other historical values range from 12 to $100 \mathrm{ug} / \mathrm{L}$, with the exception of one other value of approximately $250 \mathrm{ug} / \mathrm{L}$. The PWMS concentrations ranged from $14 \mathrm{ug} / \mathrm{L}$ to 128 $\mathrm{ug} / \mathrm{L}$, all well within the range historically observed in samples obtained from MCB-5.

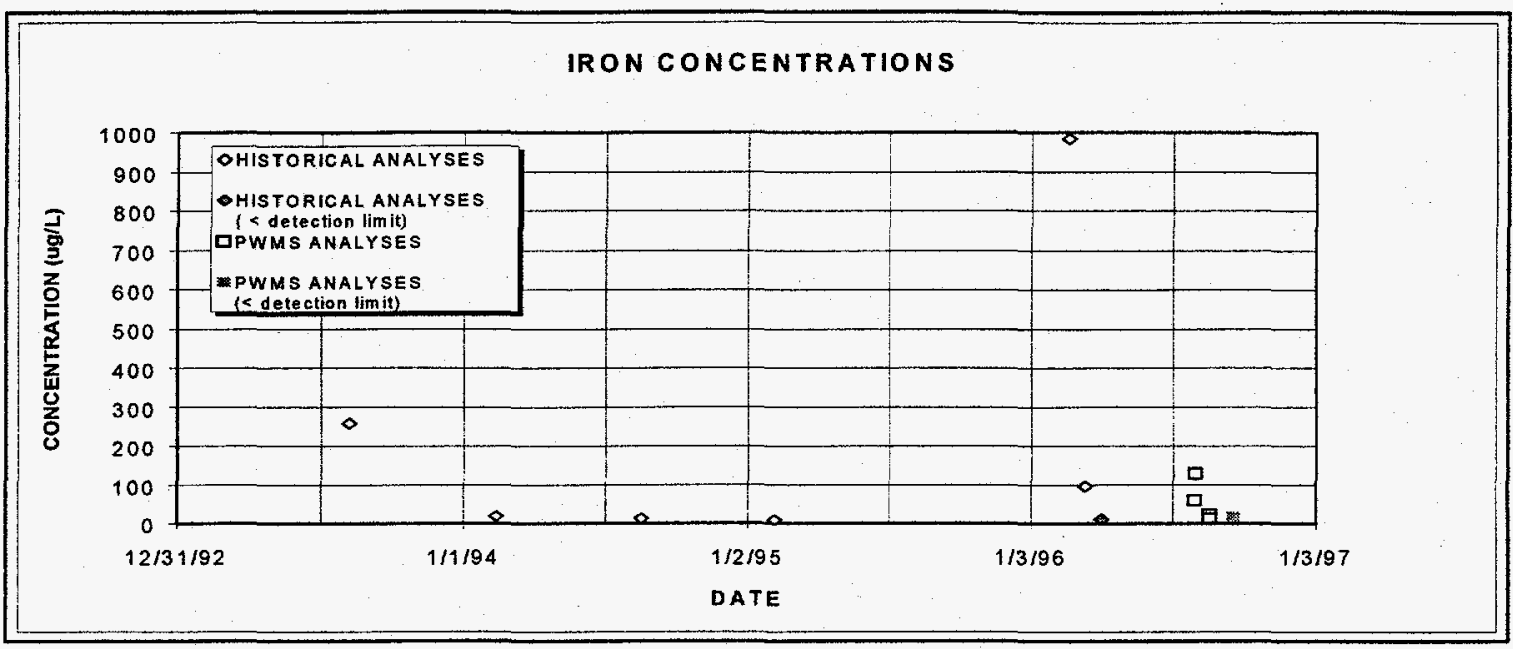

3.8 Lead There is only one historical analysis for lead that indicated a concentration higher than the analysis method detection limit. This analysis yielded a concentration of approximately $3.5 \mathrm{ug} / \mathrm{L}$. Five other analyses did not detect lead in concentrations above the detection limit, which ranged from $2 \mathrm{ug} / \mathrm{L}$ to $5 \mathrm{ug} / \mathrm{L}$. The PWMS sample analyses indicated elevated levels of lead, ranging from $9 \mathrm{ug} / \mathrm{L}$ to 19 $\mathrm{ug} / \mathrm{L}$. Two of the samples did not have lead in concentrations greater than $5 \mathrm{ug} / \mathrm{L}$, including the sample collected during the special sample event on $9 / 18 / 96$. One possible explanation of this is that trace levels of lead were introduced by segments of the PWMS piping apparatus, some of which were constructed using carbon steel. The piping had been removed prior to the collection of the sample on $9 / 18 / 96$. The use of carbon steel will be avoided in any future field applications of the PWMS.

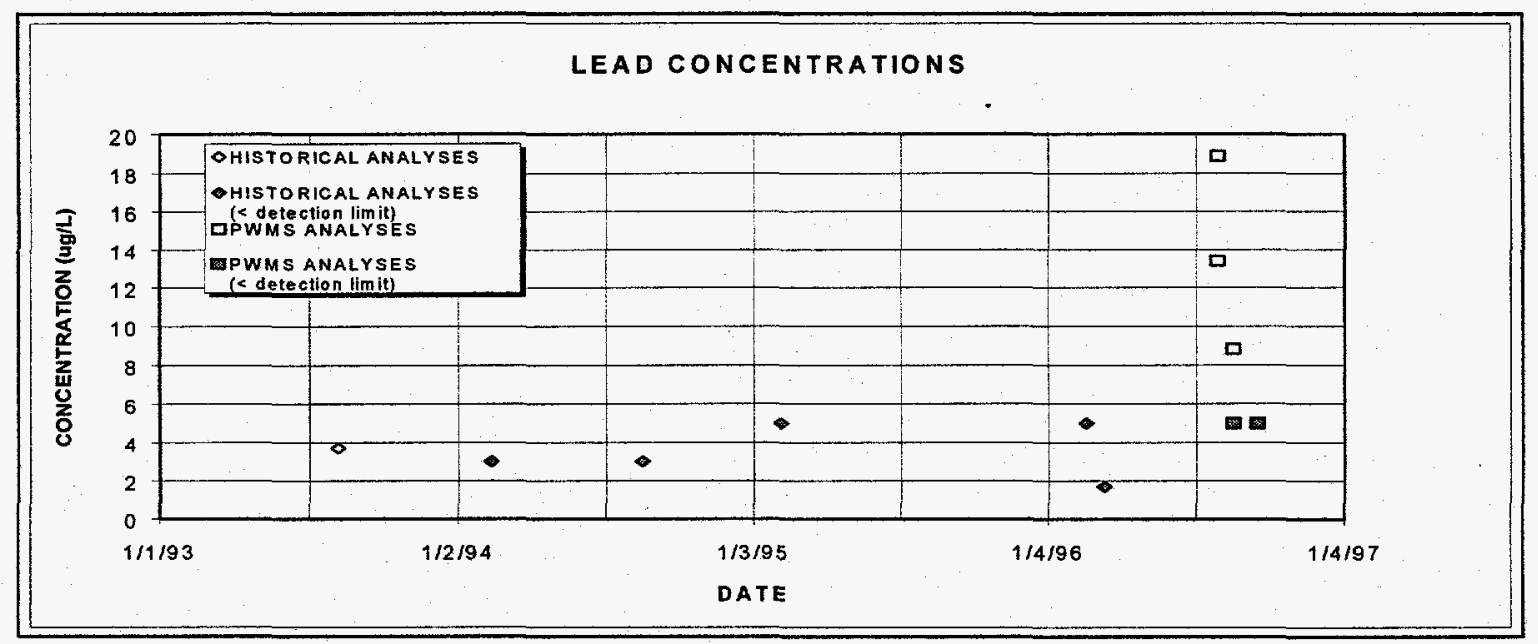


3.9 Manganese Historical Manganese concentrations in samples obtained from MCB-5 ranged from approximately 5 to 55 ug/L. A single concentration of $55 \mathrm{ug} / \mathrm{L}$ was obtained in 1993 but all concentrations cluster closely around $9 \mathrm{ug} / \mathrm{L}$ since that time. Concentrations obtained in the PWMS study ranged from 3 to $14 \mathrm{ug} / \mathrm{L}$, with influent samples concentrations being lower than effluent sample concentrations. It is possible that the metal piping segments introduced trace amount of manganese, especially since the concentration obtained on $9 / 18 / 96$ yielded a manganese concentration of less than $1 \mathrm{ug} / \mathrm{L}$. The use of carbon steel will be avoided in any future field applications of the PWMS.

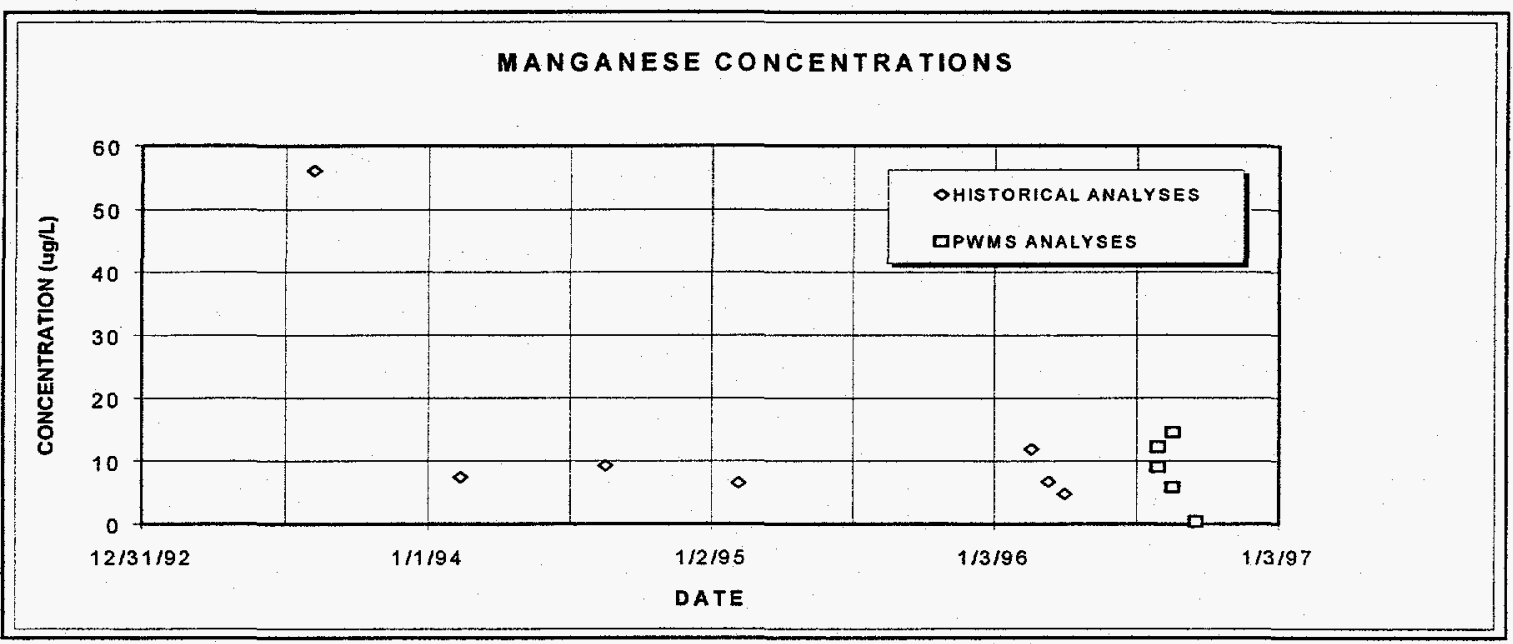

3.10 $\mathrm{pH} \quad$ Historical pH levels in MCB-5 have ranged from 6.5 to 8.0 . A decreasing trend since the beginning of 1992 is noted and the most recent three measurements suggest the trend has stabilized at approximately 6.6. The PWMS samples ranged in $\mathrm{pH}$ from about 6.3 to 6.5 , all very similar to the three most recent values obtained from MCB-5.

pH VALUES

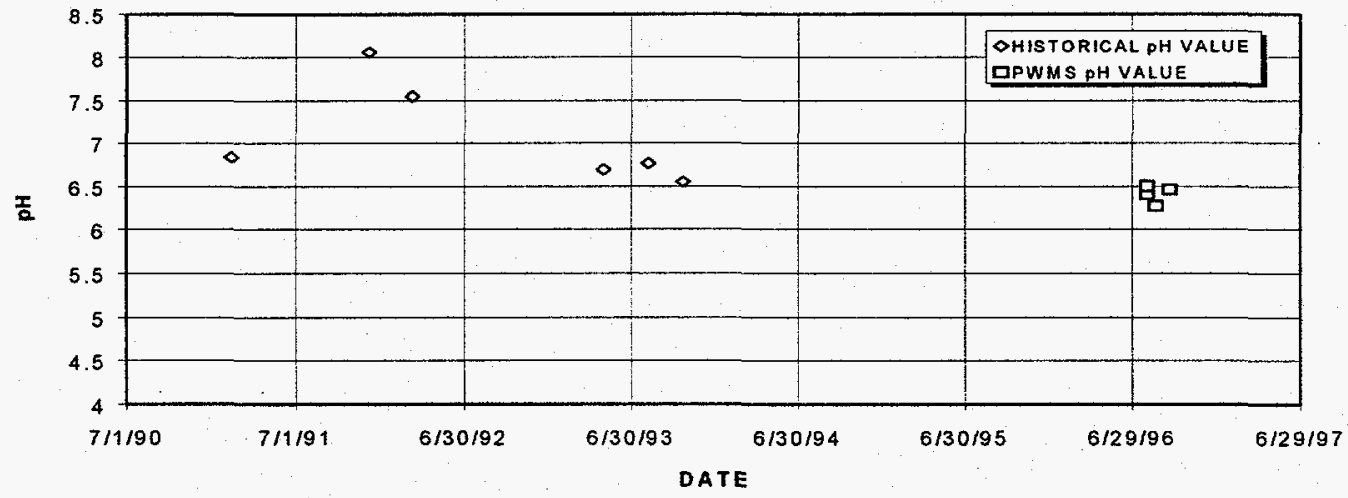


3.11 Potassium Only three historical analyses for potassium were obtained for MCB-5, ranging in concentration from approximately 130 to $370 \mathrm{ug} / \mathrm{L}$. The PWMS investigation sample concentrations of potassium ranged from approximately 90 to $170 \mathrm{ug} / \mathrm{L}$, and averaged approximately 135 $\mathrm{ug} / \mathrm{L}$. This average is very close to the concentration of two of the historical values.

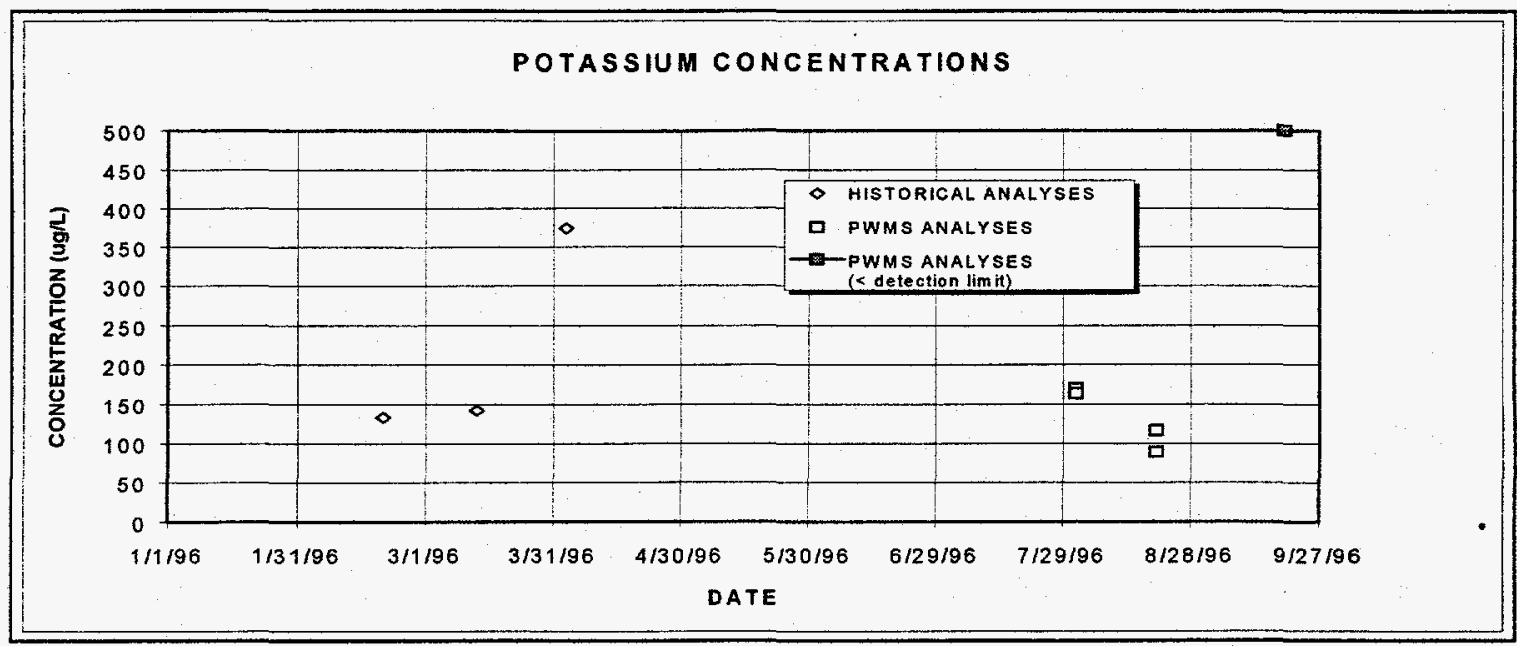

3.12 Silica No historical analyses for silica have been conducted at MCB-5 and there is no basis for comparison of PWMS sample concentrations with historical concentrations. The PWMS analysis concentrations which had values greater than the detection limit were clustered around $8000 \mathrm{ug} / \mathrm{L}$.

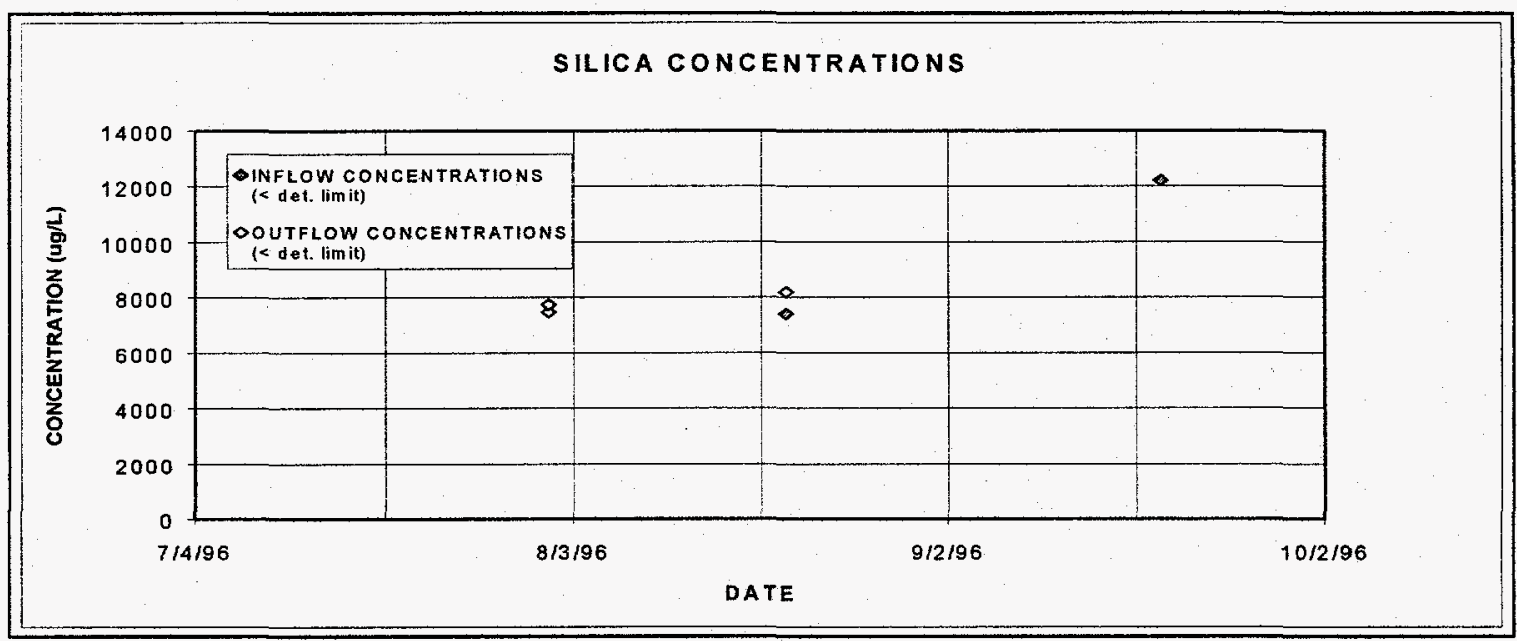


3.13 Sodium There is no record of any analyses for Sodium having been conducted at MCB-5 prior to the PWMS investigation sampling. As such there is no basis for comparison. The Phase I and Phase II sampling events yielded concentrations very similar in Sodium concentration in both influent and effluent events. The special sampling event conducted on $9 / 18 / 96$ yielded a concentration of approximately $7500 \mathrm{ug} / \mathrm{L}$. There is no suitable explanation for this anomalous concentration.

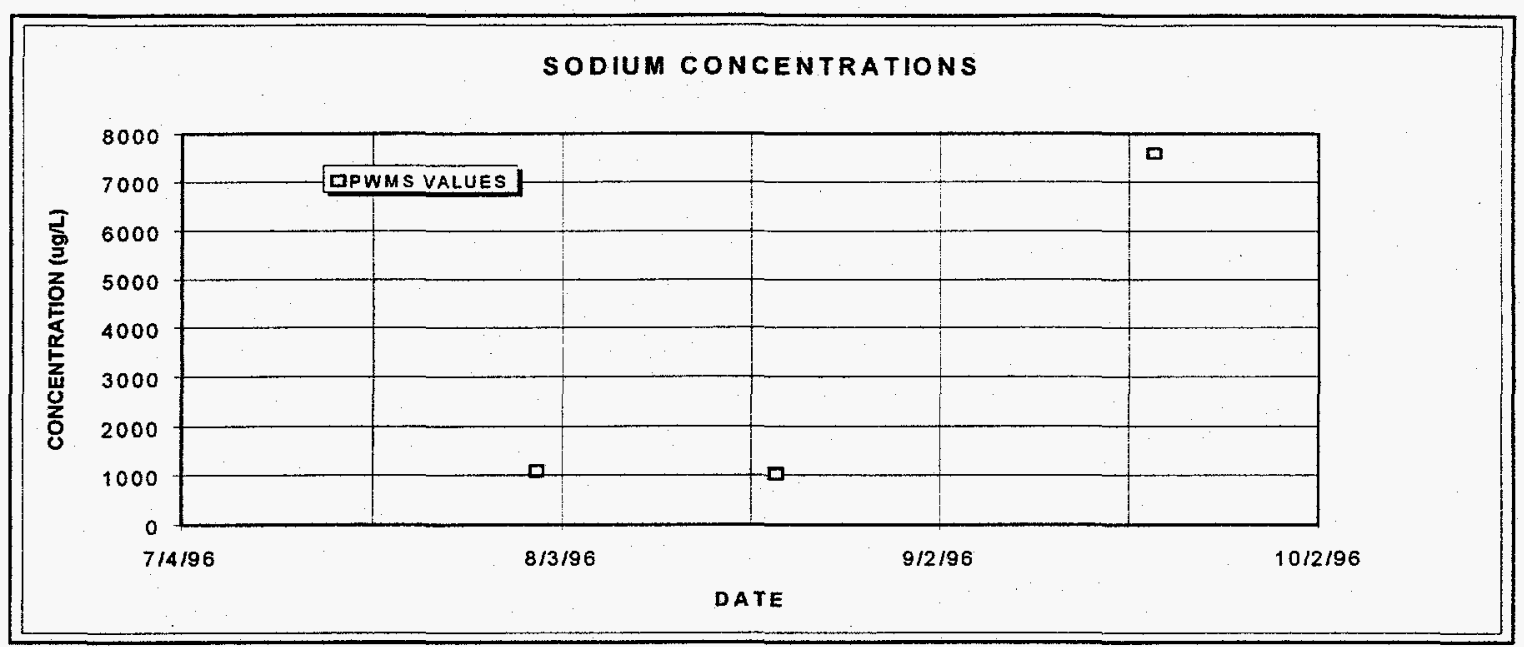

3.14 Specific Conductance Historical values of Specific Conductance have varied from around 18 to $53 \mathrm{uS} / \mathrm{cm}$ since 1991 . The PWMS investigation samples obtained
Specific Conductances ranging from approximately 33 to $40 \mathrm{uS} / \mathrm{cm}$, well within the historical range and very close to the historical average.

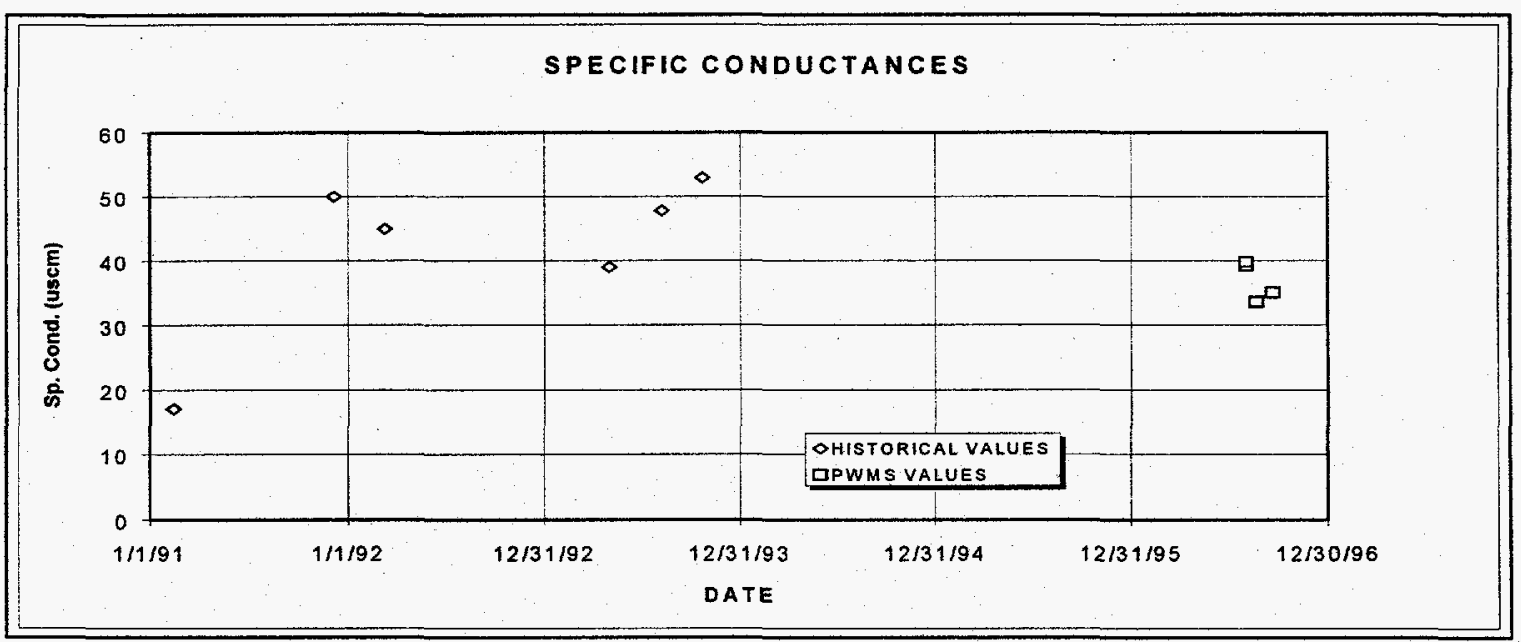


3.15 Tetrachloroethylene Historical concentrations of Tetrachloroethylene in samples collected from MCB-5 vary from approximately 12 to $70 \mathrm{ug} / \mathrm{L}$. The majority of the analyses (13 of 14) fall between 12 and $23 \mathrm{ug} / \mathrm{L}$ while a single concentration of 70 $\mathrm{ug} / \mathrm{L}$ falls outside of three standard deviations from the population mean and is considered an outlier. PWMS sample concentrations for PCE range from around 10 to $15 \mathrm{ug} / \mathrm{L}$ and are very similar to the most recent historical concentrations from MCB-5.

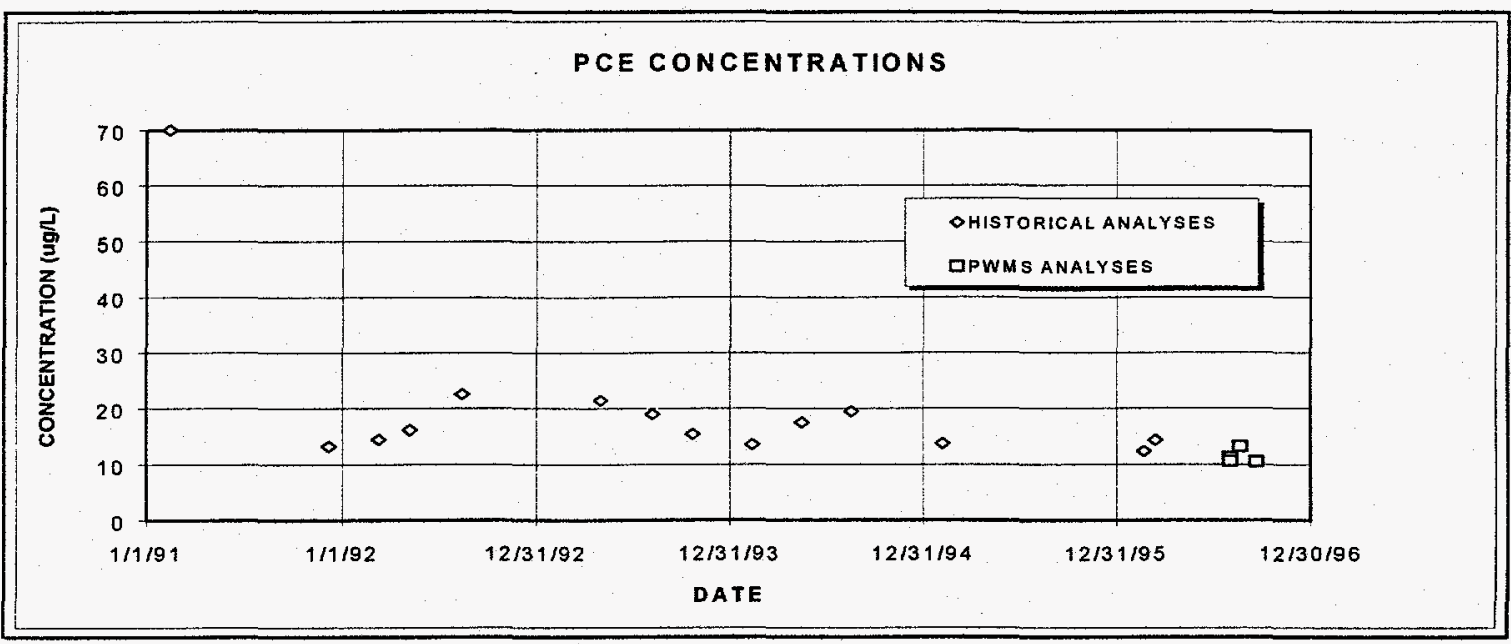

\subsection{Trichloroethylene Historical} concentrations of TCE at MCB-5 vary from 14 to $647 \mathrm{ug} / \mathrm{L}$ although the single value of $647 \mathrm{ug} / \mathrm{L}$ appears to be an outlier falling outside of three standard deviations from the population mean. Most historical analysis concentrations fall within the range from 100 to $200 \mathrm{ug} / \mathrm{L}$. The PWMS investigation analyses obtained concentrations ranging from 142 to 161 $\mathrm{ug} / \mathrm{L}$, and appear to be clustered near the mean concentration for historical analyses.

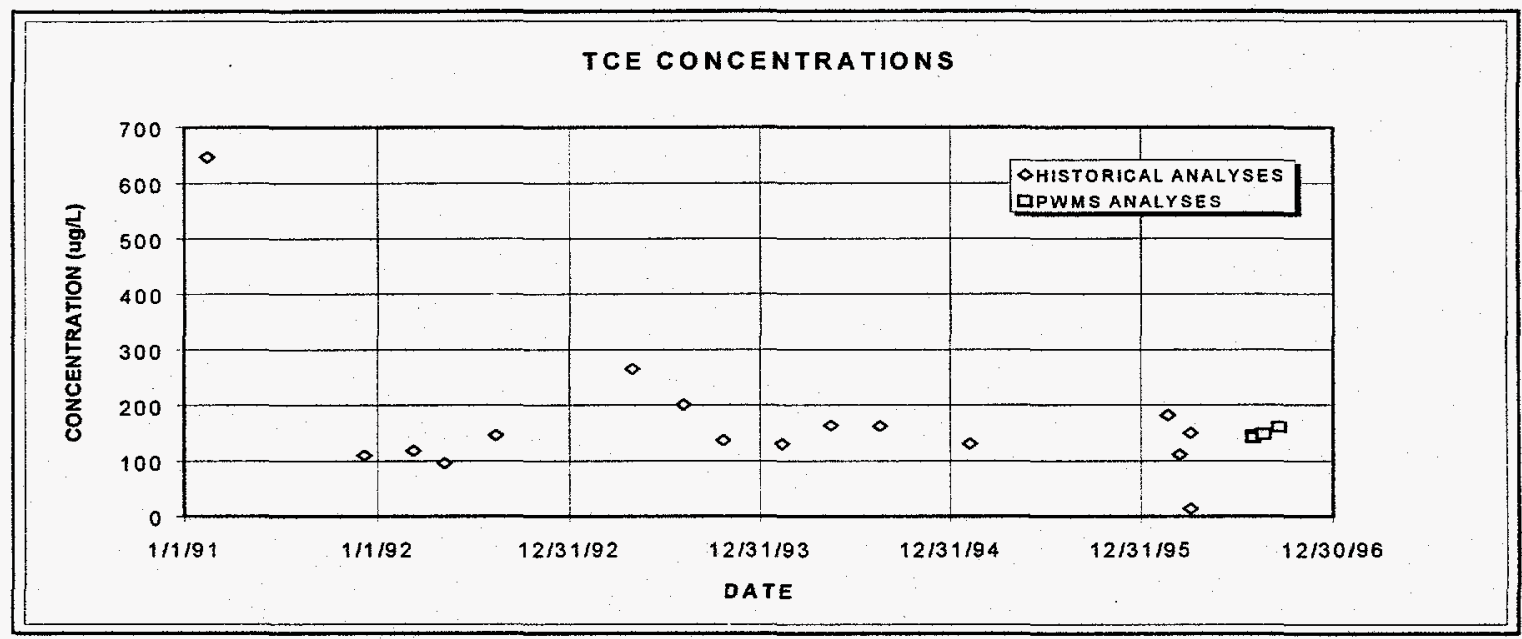




\subsection{DISCUSSION OF FINDINGS}

To facilitate comparison of the PWMS sample analysis results with historical analytical results and between the results of influent and effluent sampling events, averaged analyte concentration or parameter values were calculated for each of those categories and are presented below in Table 1.

As discussed in the RESULTS section, the issue of how to handle analysis results that were reported as "less than" the method detection limit was addressed by eliminating those values from the calculation altogether. The issue of handling duplicate, replicate and split samples was addressed by averaging these results to provide a single value which was then averaged with analysis results from different times and/or dates to obtain the values that appear in Table 1.

Two methods of calculating historical averages were utilized. The first method included all historical results for the analyte or parameter being considered and calculated the average using all values. The second method utilized only the four most recent results for the analyte or parameter being considered, eliminated the highest and lowest values and averaged the remaining two. This was intended to provide a means to compare PWMS sample results with the most recent analysis results. In some cases there were fewer than four historical analyses, in which case the short term historical average was not calculated.

Table 1. Calculated averages for Historical, PWMS Influent, and PWMS Effluent results.

\begin{tabular}{|l|c|c|c|c|}
\hline $\begin{array}{l}\text { ANALYTE or } \\
\text { PARAMETER }\end{array}$ & $\begin{array}{l}\text { HISTORICAL } \\
\text { AVG. (all) }\end{array}$ & $\begin{array}{l}\text { HISTORICAL * } \\
\text { AVG. (recent hist.) }\end{array}$ & $\begin{array}{l}\text { INFLUENT } \\
\text { SAMPLES }\end{array}$ & $\begin{array}{c}\text { EFFLUENT } \\
\text { SAMPLES }\end{array}$ \\
\hline & & & & \\
\hline Aluminum & 324 & 87 & 41 & 142 \\
\hline Calcium & 4417 & & 3386 & 4759 \\
\hline Carbon Tetrachloride & 5.8 & 3.7 & 4 & 4 \\
\hline Chloride & 1586 & 1510 & 1695 & 1800 \\
\hline Chromium & 1.3 & & 1.3 & 1.5 \\
\hline Gross Alpha & 1.5 & 1.7 & 1.4 & 1.3 \\
\hline Iron & 229.7 & 55 & 37.4 & 76.1 \\
\hline Lead & 3.7 & & 18.9 & 11.1 \\
\hline Manganese & 14.7 & 6.7 & 5.1 & 13.4 \\
\hline pH & 7.1 & 6.7 & 6.4 & 6.5 \\
\hline Potassium & 216.3 & & 143 & 126.7 \\
\hline Silica & & & $<$ det. limit & $<$ det. limit \\
\hline Sodium & & & 3236 & 1056 \\
\hline Specific Conductance & 42 & 46.4 & 36 & 36.8 \\
\hline Tetrachloroethylene & 19.9 & 6.7 & 11.7 & 10.6 \\
\hline Trichloroethylene & 183.5 & 141 & 151.3 & 142 \\
\hline
\end{tabular}

Note: All units in ug/L, except for Gr. Alpha in $\mathrm{pCi} / \mathrm{L}, \mathrm{Sp}$. Cond. in $\mathrm{uS} / \mathrm{cm}$, no units for $\mathrm{pH}$.

* Formula $=$ use 4 most recent quarters, eliminate high and low values, average remaining two. 
The average PWMS influent and effluent concentrations for the 16 parameters are reported in the "INFLUENT" and "EFFLUENT" columns. These values are average from analyses conducted on samples obtained during the Phase I, Phase II and "special" sampling events.

A table of analytical results of the 16 analytes and field parameters for the PWMS samples is provided in the APPENDIX along with bar charts graphically illustrating the results. These charts allow an examination of any differences related to when the samples were collected relative to filling and draining of the bladder tank. The table also presents the results of rinsate and QA samples that were obtained and these are also displayed on the charts, for reference. These samples are labeled EPT-1, $-2,-3$, and -4 . The Influent and effluent samples are labeled as MCB-5-I or MCB-5-O to designate "Influent" versus "Effluent" and are each associated with a specific date on which a sampling event was conducted. A description of exactly when samples were collected has been presented earlier in the report.

When the influent samples were collected, the field parameters of $\mathrm{pH}$, specific conductance and turbidity were monitored and the protocol sample was collected after all the parameters had stabilized. During the three sampling events $\mathrm{pH}$ and specific conductance values were steady, right from the beginning. In each instance turbidity was initially elevated and gradually restabilized over a period ranging from several minutes to 30 minutes. The effluent samples were collected after the purge water had resided in the bladder tank. Analyses of this water reflects the mixing of relatively turbid water with non-turbid water. This leads to a "turbidity effect", in which the effluent samples for several analytes, most notably aluminum, have elevated concentrations compared to influent samples. The average aluminum concentration for effluent samples was 142 $\mathrm{ug} / \mathrm{L}$ compared to $41 \mathrm{ug} / \mathrm{L}$ for the influent samples, while the recent historical average is $87 \mathrm{ug} / \mathrm{L}$. In addition, iron, manganese and calcium concentrations are slightly higher for effluent samples compared to influent samples. Despite this slight elevation, effluent sample concentrations for iron and manganese are less than historical averages from MCB-5. In the case of Iron, the historical average is probably biased upward by the inclusion of a suspect analysis (993 ug/L) in the averaging.

The following is a parameter by parameter discussion of the average concentrations or values noted in Table 1 .

Aluminum: Average concentrations for influent and effluent samples were quite different, the effluent samples having an average concentration of $142 \mathrm{ug} / \mathrm{L}$ while the influent samples had an average value of $41 \mathrm{ug} / \mathrm{L}$. This discrepancy is attributable to the turbidity effect, since aluminum is a major constituent of clay molecules. The influent sample was not collected until the initially turbid water had passed the sampling point while the effluent sample was taken from the water which collected and was mixed inside the bladder. The historical levels of aluminum were 324 and $87 \mathrm{ug} / \mathrm{L}$ for the two methods used to calculate the historical level. The levels of aluminum concentration obtained in this study are consistent with the most recently acquired aluminum concentrations.

Calcium: Concentration for influent and effluent samples were similar, however the effluent samples were slightly higher with $4759 \mathrm{ug} / \mathrm{L}$ vs. $3386 \mathrm{ug} / \mathrm{L}$ for the influent samples. Likewise the historical concentrations were similar to the concentrations obtained in the PWMS study. The historical average was $4417 \mathrm{ug} / \mathrm{L}$ while the most recent historical values were $4880 \mathrm{ug} / \mathrm{L}$ (note: only 3 historical values, so the middle one was used) 
Carbon Tetrachloride: Concentrations of carbon tetrachloride taken from influent and effluent samples were identical at $4 \mathrm{ug} / \mathrm{L}$ and were very close to each of the historical averages, 5.8 and $3.7 \mathrm{ug} / \mathrm{L}$.

Chloride: Chloride concentrations in the influent samples and effluent samples were very close, being 1695 and $1800 \mathrm{ug} / \mathrm{L}$, respectively. These concentrations are very slightly higher than the historical concentrations of 1586 and $1510 \mathrm{ug} / \mathrm{L}$ but are still quite similar.

\section{Chromium: Concentrations of influent} and effluent concentrations of chromium are practically identical to one another as well as with historical concentrations. Note that all concentrations fall within the range from 1.3 to $1.7 \mathrm{ug} / \mathrm{L}$.

Gross Alpha: The gross alpha activity is remarkably similar in both the PWMS study samples and historical samples. The range of activities was from 1.3 to $1.7 \mathrm{pCi} / \mathrm{L}$. Influent sample average activity was 1.4 $\mathrm{pCi} / \mathrm{L}$ while the effluent sample average activity was $1.3 \mathrm{pCi} / \mathrm{L}$. Historical activity levels were 1.5 and $1.7 \mathrm{pCi} / \mathrm{L}$ for the longterm historical average and the recent historical average, respectively.

Iron: Concentrations for influent and effluent samples were quite different, the effluent samples having an average concentration of $76.1 \mathrm{ug} / \mathrm{L}$ while the influent samples had an average value of $37.4 \mathrm{ug} / \mathrm{L}$. This discrepancy is likely attributable to the turbidity effect, owing to the accumulation of iron on clay molecules. The influent sample was not collected until the initially turbid water had passed the sampling point while the effluent sample was taken from the water which collected and was mixed inside the bladder. The short-term average historical concentration of iron, at $55 \mathrm{ug} / \mathrm{L}$, is similar to the PWMS sampling concentrations. The longer term historical average is much higher, $233.7 \mathrm{ug} / \mathrm{L}$. This is due to the incorporation of a single concentration of $983 \mathrm{ug} / \mathrm{L}$ from 1Q96 that is eliminated in the formula for calculating short-term historical average. The reason for the anomalous concentration of iron in that sample is not clear.

Lead: Concentrations of lead were very slightly different for influent and effluent samples. Influent concentrations averaged $18.9 \mathrm{ug} / \mathrm{L}$ while effluent samples averaged $11.1 \mathrm{ug} / \mathrm{L}$. This difference might be misleading since the influent concentration is based upon a singie analysis since two other influent analyses are ignored because they were not detected in measurable concentrations, i.e. $>$ the detection limit of 5 ug/L. Likewise the near and short-term historical averages of $3.7 \mathrm{ug} / \mathrm{L}$ are misleading because both derive from a single analysis result $>$ the detection limit. There are five other historical analyses that yielded concentrations < the detection limits of 3 or $5 \mathrm{ug} / \mathrm{L}$. It appears that the groundwater contains very low levels of lead and the results suggests that the samples may be acquiring some trace amount of lead from the PWMS piping assembly.

Manganese: Concentration of manganese were similar between inflow and outflow samples. Inflow concentrations averaged $5.1 \mathrm{ug} / \mathrm{L}$ while outflow concentrations averaged $13.4 \mathrm{ug} / \mathrm{L}$. The inflow samples contained one anomalously low concentration of $0.4 \mathrm{ug} / \mathrm{L}$ while the other concentrations were only slightly lower than the outflow concentration average. Long and short-term average concentrations for manganese were 14.7 and $6.7 \mathrm{ug} / \mathrm{L}$, again similar to the PWMS sample concentrations.

$\mathrm{pH}$ : $\quad$ PWMS $\mathrm{pH}$ levels from influent and effluent samples are very similar, averaging 6.4 and 6.5 , respectively. The historical and recent values of $\mathrm{pH}$ were 7.1 and 6.7 , the recent historical value being very close to the PWMS values. 
Potassium: The potassium concentrations from influent and effluent samples are quite similar at 143 and 126.7 $\mathrm{ug} / \mathrm{L}$, respectively. These concentrations are somewhat lower than the historical average concentration of $216.3 \mathrm{ug} / \mathrm{L}$

Silica: No comparison can be made between influent and effluent sample analyses for silica because the analyses that were conducted obtained values less than the method detection limit. The analytical results were provided with a "V" qualifier which means that silica was detected in the method blank and that the analytical results are essentially less than the $5 \mathrm{X}$ rule.

Sodium: The average concentrations obtained for Influent and effluent samples for sodium appear to be quite different, being $3236 \mathrm{ug} / \mathrm{L}$ for influents samples and $1056 \mathrm{ug} / \mathrm{L}$ for the effluent samples.

However, the average influent value shown in Table 1 includes a single value of 7590 ug/L obtained during the Special Sampling Event which is thought to be of suspect validity. When this value is ignored, the influent sample average is $1064 \mathrm{ug} / \mathrm{L}$, practically identical to the average effluent concentration (1056 ug/L) and very similar to all historical concentrations obtained at MCB-5. Because the Sodium concentration from the Special Sampling Event is anomalous there will be continued monitoring for Sodium in future sampling events during the PWMS deployment phase.

Specific Conductance: Specific conductance values are practically identical from influent to effluent samples. The values obtained averaged 36 and 36.8 $\mathrm{mS} / \mathrm{cm}$, respectively, for these sample events.

Tetrachloroethylene: Average concentration for influent and effluent samples were practically identical, 11.7 $\mathrm{ug} / \mathrm{L} 10.6 \mathrm{ug} / \mathrm{L}$, respectively.

\section{Trichloroethylene: Concentration} variation between influent and effluent samples was very slight with the average influent concentration being $151.3 \mathrm{ug} / \mathrm{L}$ while the average effluent concentration was $142 \mathrm{ug} / \mathrm{L}$. 


\subsection{CONCLUSIONS AND RECOMMENDATIONS}

Evaluation of the analytical results obtained during the Phase I, Phase II and the 9/18/96 sampling events at MCB-5 indicates that samples collected using the PWMS sampling method yield analysis results that are very similar to historical analysis results obtained from traditional sampling methods. Based on this observation it is reasonable to conclude that representative groundwater samples are being collected using the PWMS method. This is indicated not only for background analytes, but also for contaminants that have been released to the subsurface in the vicinity of the Miscellaneous Chemicals Basin.

The PWMS well sampling methodology is suitable for utilization in the groundwater monitoring program at SRS. Although the methodology would be a cost-effective alternatlive for monitoring any well having contaminated groundwater, the advantage of foregoing the need to containerize, transport and dispose of contaminated purge water is particularly attractive for wells that generate purge water that is difficult and/or expensive to dispose of. Such wells include those whose purge water contains radioactive waste, mixed radioactive-hazardous wastes, or waste designated as listed waste.

The PWMS well sampling method should be implemented in wells at several waste sites across the Savannah River Site on a demonstration basis. Wells should be selected to demonstrate the advantage of the method for wells whose primary contaminants represent the most common ones found at SRS. It is suggested that one site be at the Sanitary Landfill, one at the General Separations Area, and one site at a former reactor area. Other sites could be considered as well. All future implementation of PWMS should avoid the use of carbon steel in the construction of piping apparatus to avoid any possibility of introduction of metallic cations into water samples. 


\subsection{REFERENCES}

WSRC-RP-94-1227, Investigation Derived Waste Management Plan, Rev. 2. Westinghouse Savannah River Company, Aiken, South Carolina, 29808. 


\section{APPENDIX}

Table of Analytical Results, containing charts, listing analyte concentrations and field parameters for the MCB-5-I, MCB-5-O, and EPT-1, $-2,-3$, and -4 sampling events. 


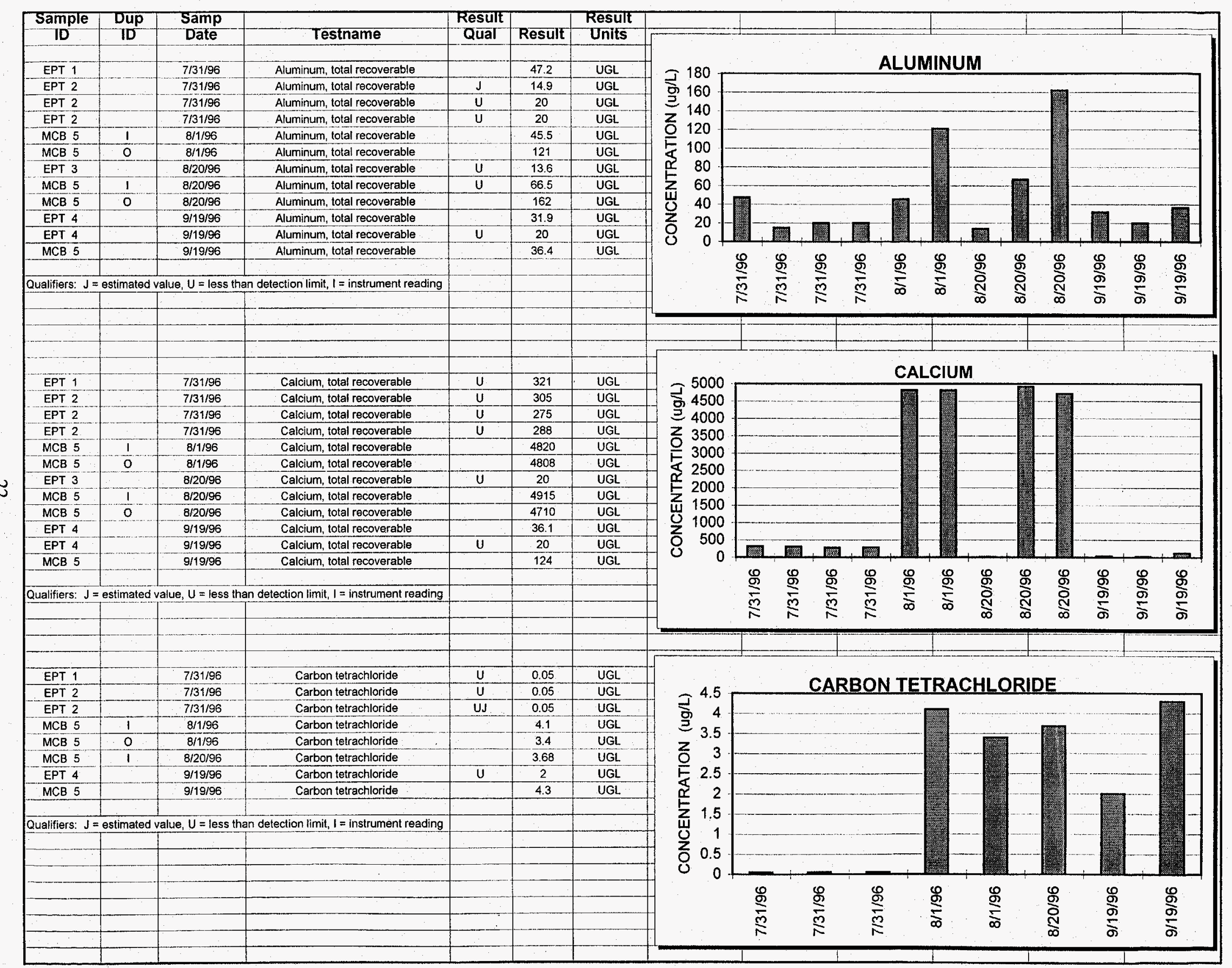




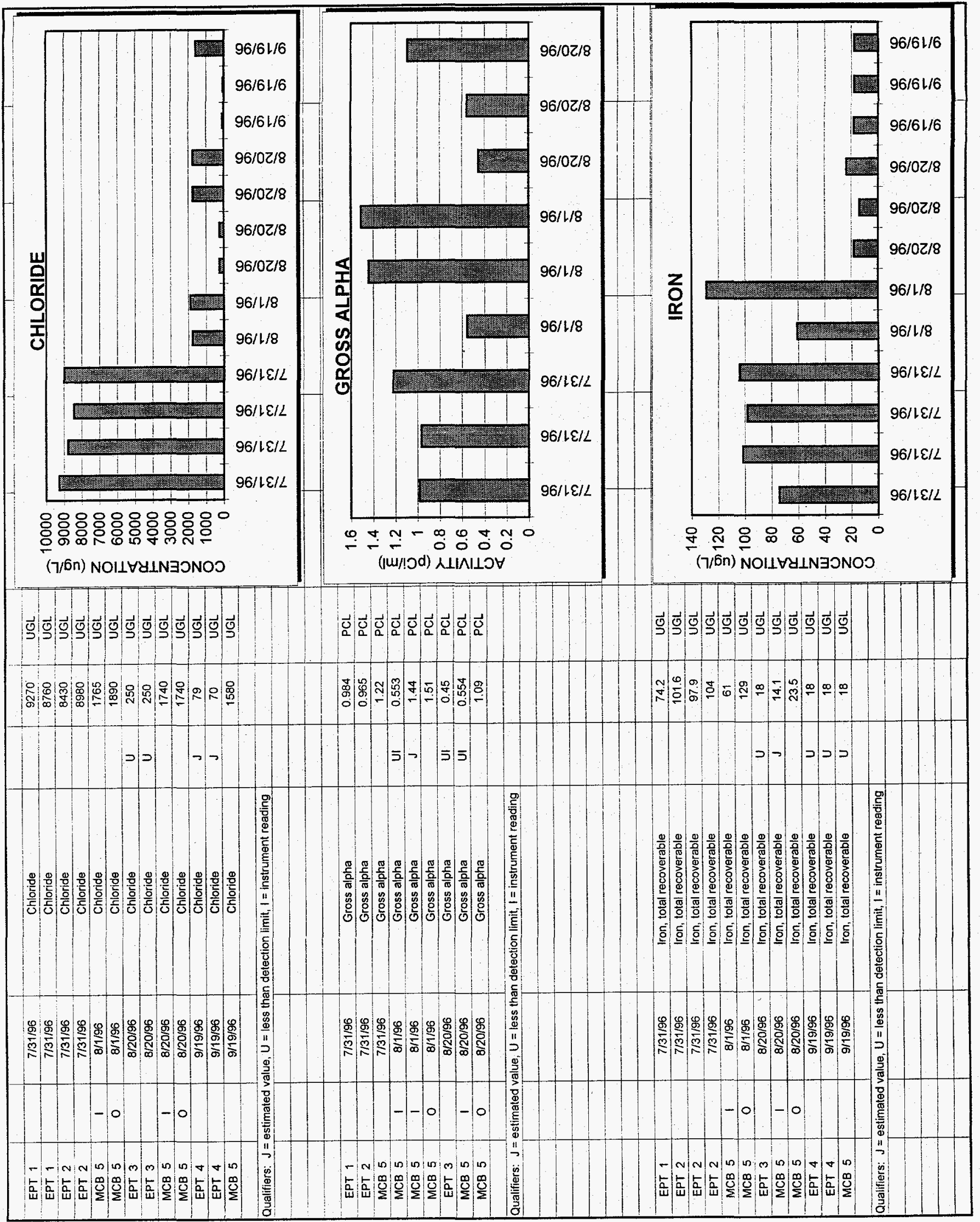




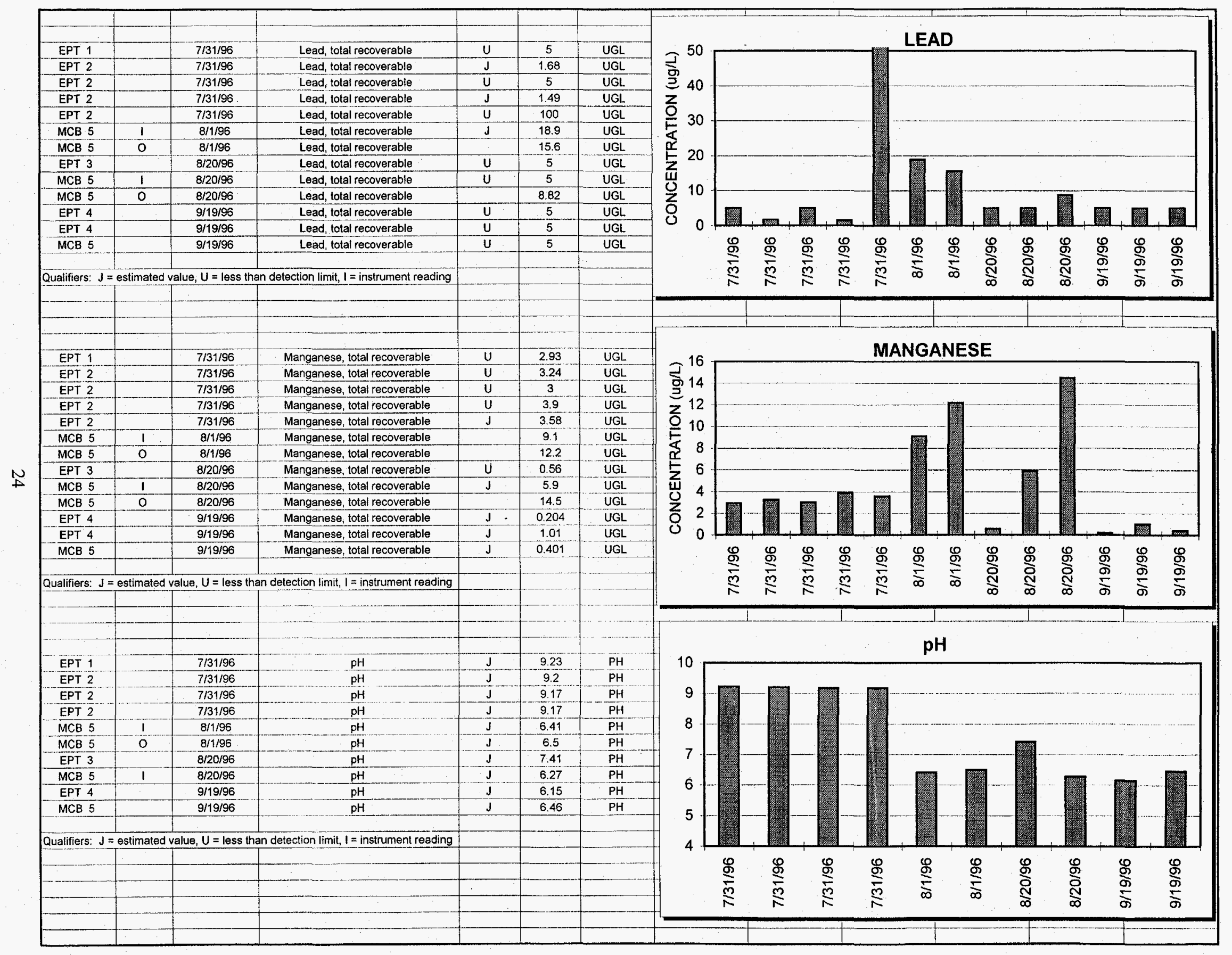




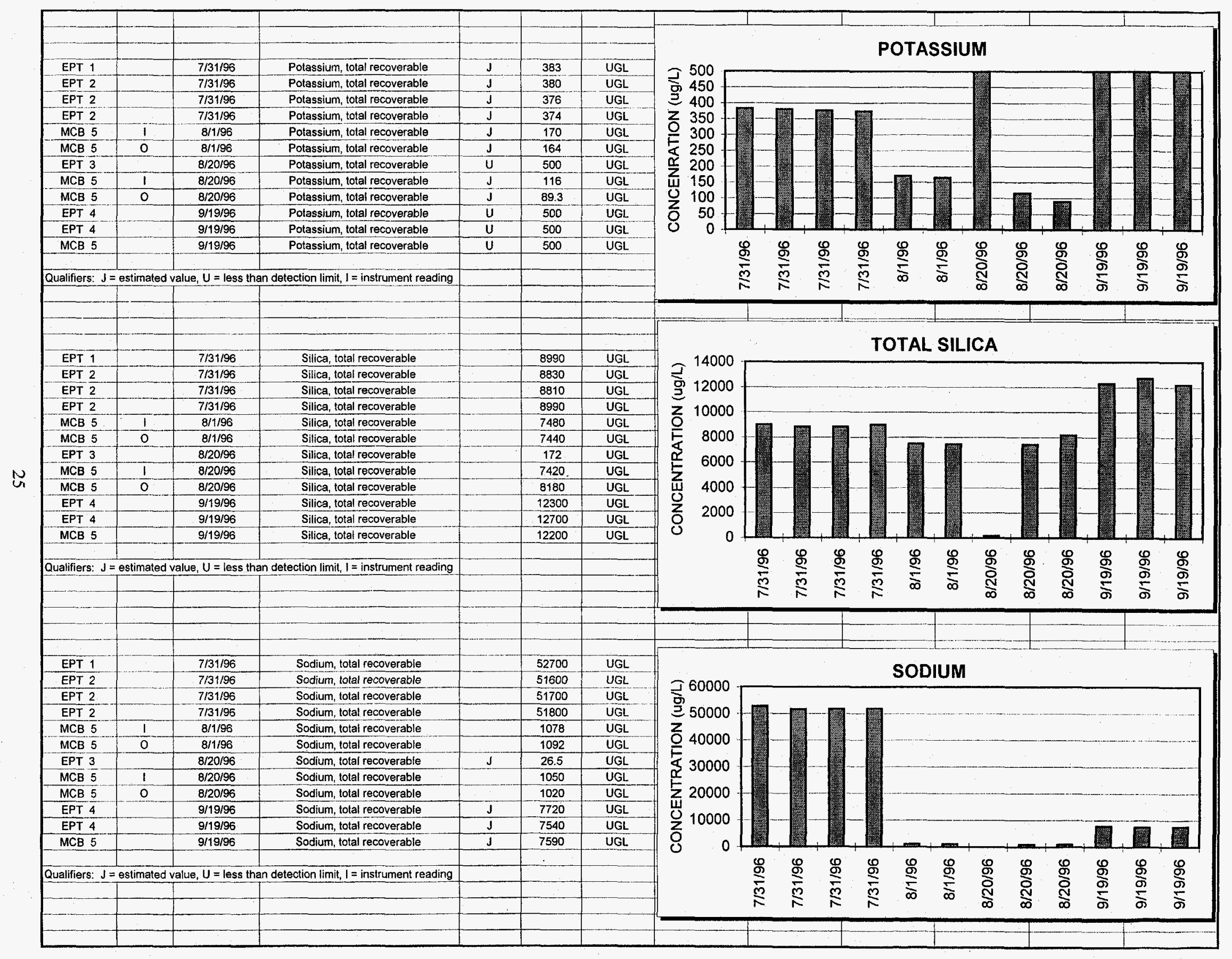




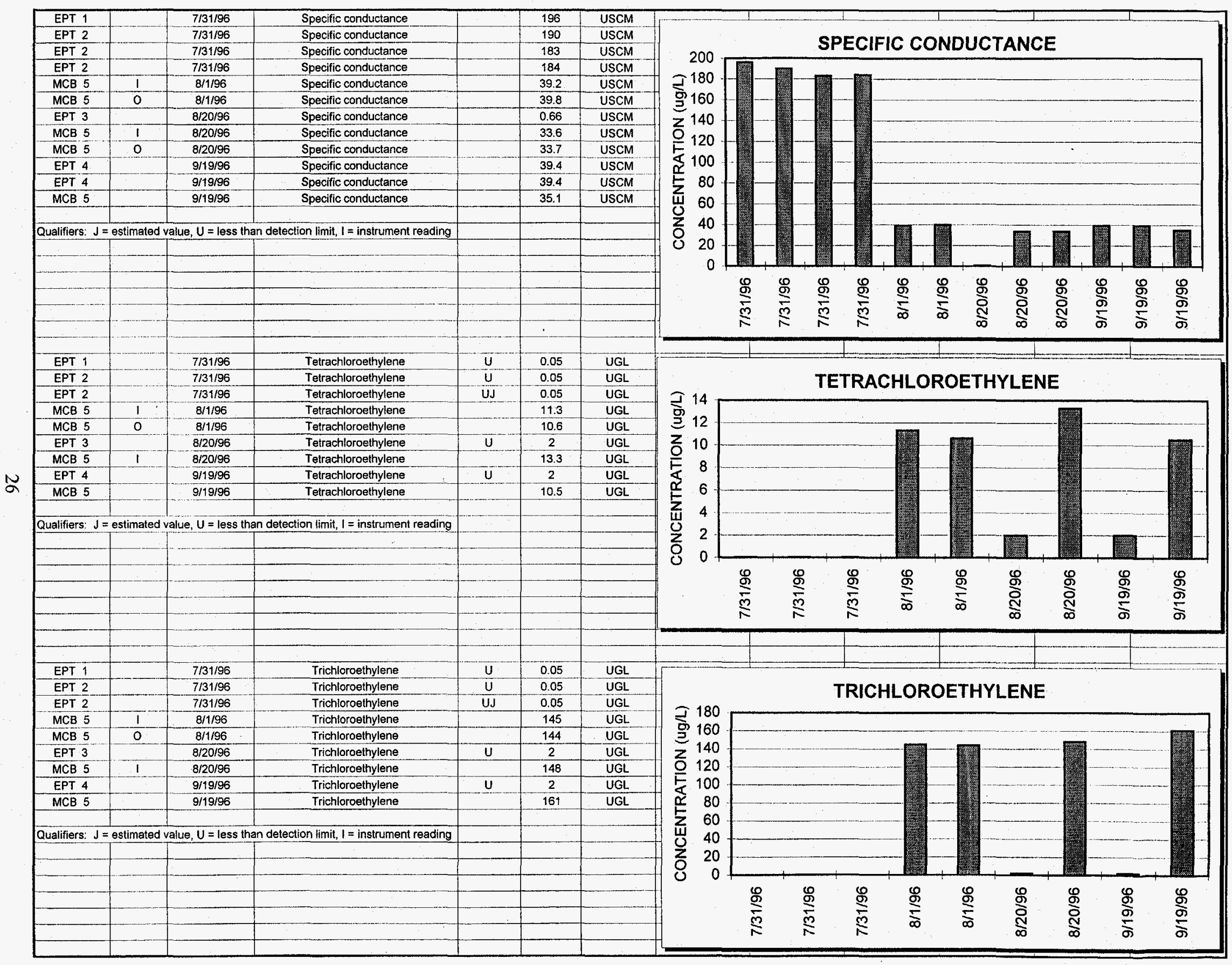

